Article

\title{
A Field Study on Thermal Comfort and Cooling Load Demand Optimization in a Tropical Climate
}

\author{
Masoud Esfandiari ${ }^{1}$ (D), Suzaini Mohamed Zaid ${ }^{2, *(D)}$, Muhammad Azzam Ismail ${ }^{2}$, Mohammad Reza Hafezi ${ }^{1}$, \\ Iman Asadi ${ }^{3}$ (D) and Saleh Mohammadi $4,5, *$ (D)
}

1 Faculty of Architecture and Urban Planning, Shahid Beheshti University, Tehran 19839-69411, Iran; a.m.esfandiari@gmail.com (M.E.); mr-hafezi@sbu.ac.ir (M.R.H.)

2 Faculty of Built Environment, University of Malaya, Kuala Lumpur 50603, Malaysia; ma.ismail@um.edu.my

3 Department of Structural Engineering, Norwegian University of Science and Technology, NO-7491 Trondheim, Norway; iman.asadi@ntnu.no

4 Department of Architectural Engineering and Technology, Faculty of Architecture and the Built Environment, Delft University of Technology, 2628 BL Delft, The Netherlands; s.mohammadi@saxion.nl

5 Department of Sustainable Building Technology, School of Business Building and Technology, Saxion University of Applied Sciences, P.O. Box 70.000, 7500 KB Enschede, The Netherlands

* Correspondence: suzaini_zaid@um.edu.my (S.M.Z.); saleh.mohammadi@tudelft.nl (S.M.)

check for updates

Citation: Esfandiari, M.; Zaid, S.M.; Ismail, M.A.; Hafezi, M.R.; Asadi, I.; Mohammadi, S. A Field Study on Thermal Comfort and Cooling Load Demand Optimization in a Tropical Climate. Sustainability 2021, 13, 12425. https://doi.org/10.3390/ su132212425

Academic Editors: José Dinis Silvestre and Zsuzsa Szalay

Received: 12 September 2021

Accepted: 5 November 2021

Published: 10 November 2021

Publisher's Note: MDPI stays neutral with regard to jurisdictional claims in published maps and institutional affiliations.

Copyright: (c) 2021 by the authors. Licensee MDPI, Basel, Switzerland. This article is an open access article distributed under the terms and conditions of the Creative Commons Attribution (CC BY) license (https:/ / creativecommons.org/licenses/by/ $4.0 /)$.

\begin{abstract}
Energy consumption to cool an indoor environment is a substantial part of total energy end-use, particularly in a tropical climate with high energy demand for cooling. To improve energy efficiency, cooling systems can be optimized using a variety of neutral indoor temperatures to maintain a balance between an occupant's thermal comfort and cooling energy demand. This explanatory study investigated the thermal quality and cooling energy demand of a Platinumcertified office building in the tropical climate of Malaysia. The investigation aimed to suggest a balance between occupant thermal comfort and cooling energy demand. The thermal investigation includes an objective field measurement that implements environmental equipment to monitor thermal quality and a subjective occupant's thermal feedback using a questionnaire survey. To calculate cooling energy demand, the total equivalent temperature difference method (TETD) is applied. The results suggested an occupant's cooling sensation of around $24{ }^{\circ} \mathrm{C}$, with no significant difference concerning age and gender. Cooling load calculation indicated a $36 \%$ energy reduction by increasing air temperature to $26^{\circ} \mathrm{C}$, for occupants to feel thermally comfortable in a tropical climate. These findings contribute to improving sustainable energy policies, sustainable construction, and thermal comfort improvement for a tropical climate.
\end{abstract}

Keywords: thermal quality; cooling energy demand; energy-efficient design; tropical climate; green building index

\section{Introduction}

Cooling the indoor environment is essential in tropical climates to provide thermal comfort. Within this climate, heating, ventilation, and air-conditioning (HVAC) systems are the main sources to provide indoor thermal comfort with excessive energy consumption [1]. Conversely, the power reduction in tropical climates is necessary for buildings to reduce electricity cost [2]. This can bring complications between providing thermal comfort and energy efficiency [3], particularly for green buildings aiming to reduce cooling energy demand. Thermal comfort has a direct impact on energy consumption of any building, as any occupant discomfort leads to a modification of controls to non-optimal levels [4,5]. To overcome this challenge, natural ventilation is proposed as an alternative solution $[6,7]$. However, the use of an HVAC system is still dominant in a hot-humid climate.

Among the building services, especially in tropical countries, there is a significant growth in applying HVAC systems to cool indoor environments. Statistical data shows that 
cooling systems cover $50 \%$ of building energy use and $20 \%$ of total energy consumption in the United States of America [8]. Overworking of the HVAC system in buildings can be considered as a flaw in mechanical system design, proven by thermal dissatisfaction as well as excessive energy consumption.

Hoyt and Lee [9] indicated that, by increasing cooling setpoints by $1{ }^{\circ} \mathrm{C}$, energy consumption decreases significantly up to $15 \%$ annually. Particularly for Malaysia, Kwong and Adam [2] concluded that an annual reduction of 2150 GWh energy consumption can be achieved by increasing $2{ }^{\circ} \mathrm{C}$ in the thermostat setpoint. According to PTM [10], the buildings energy index (BEI) for Malaysian office buildings stays within the range of 100 to $450 \mathrm{kWh} / \mathrm{m}^{2} /$ year. The average BEI of $250 \mathrm{kWh} / \mathrm{m}^{2} /$ year is also reported by the same source for Malaysian office buildings. However, only about $30 \%$ of office buildings in Malaysia can achieve the target of less than $220 \mathrm{kWh} / \mathrm{m}^{2} /$ year. This threshold is considered as a benchmark by Malaysian standard MS 1525 [11]. Thus, thermal comfort evaluation to determine the occupant's thermal perception and neutral temperature is a proper strategy to reduce power consumption [12].

Basically, the design and evaluation of indoor thermal comfort relies on universal standards such as ISO 7730 [13], EN 16798 [14], ASHRAE Standard 55 [15] and/or in Malaysia, MS 1525 [11]. Particularly, MS 1525 [11] was developed to address occupant comfort and minimum energy efficiency criteria for non-residential buildings. These standards mostly depend on Fanger's model to predict and define the acceptable indoor thermal environment. Fanger's PMV-PPD model was developed to illustrate thermal sensation in seven-point scales, resulting from numerous experiments on human subjects in several environments [16]. Fanger's model provides a set of equations to compute predicted mean vote (PMV) and predicted percentage dissatisfied (PPD). With this, percentages of thermally satisfied occupants can be predicted by employing the metrics PMV and PPD [8].

The PMV-PPD model is extensively applied in buildings with HVAC systems in cold and warm climates during both summer and winter. However, Nicol [17] believes that universal standards $[15,18]$ based on Fanger's PMV-PPD, do not appropriately deliver a thermally comfortable indoor environment in a tropical climate. Besides the PMV-PPD model, adaptive thermal comfort is also studied based on the climate [19-21]. These investigations are due to thermal adaptation of individuals, which is correlated with factors such as geographic location and climate, time of year, gender, race, and age [22]. For instance, Maykot and Rupp [23] indicated that the neutral temperature for females is higher than for males. Concerning the climate, Lovins [24] implied that the perception of comfort varies between different climates and is influenced by localised culture.

Regarding tropical climates, studies were conducted in countries such as Malaysia to determine acceptable indoor thermal comfort. For instance, the acceptable indoor temperature is found to range between $21-26^{\circ} \mathrm{C}$ for a variety of buildings in this climate [25-29]. In addition, Kwong and Adam [2] reviewed the literature on the thermal comfort of office buildings in tropical climates. The findings suggest a range of neutral temperatures between 24.2 and $28.3{ }^{\circ} \mathrm{C}$. Thermal dissatisfaction is one of the most common complaint sources of the indoor environment quality (IEQ) of office buildings in different climates [30,31].

To achieve an acceptable thermal quality for office buildings in a tropical country such as Malaysia, a significant portion of total electricity end usage is related to the HVAC system. Thus, determining neutral temperature is essential for different air-conditioned buildings to improve thermal comfort and to reduce excessive cooling load resulting from overworked air-conditioning systems. The cooling load is the amount of heat rate that should be removed to keep indoor temperature at a comfortable level [13].

Generally, heat gain through building envelopes, such as walls, roofs, and windows, is attributed to a major portion of the cooling load [32]. Cooling load calculation is a complicated process due to the thermal mass effect of building envelopes and the fluctuations of outdoor conditions. Although there are various methods to investigate and calculate the cooling load of buildings, the total equivalent temperature difference (TETD) is a widely accepted method to determine heat gain through the structures. TETD is a proposed method 
by ASHRAE to calculate cooling load according to heat gain in a transient condition. To calculate the cooling load in a transient condition, the dynamic thermal properties of building envelopes should be evaluated. The TETD method calculations depend on time lag and decrement factor to accurately predict cooling load [33]. Time lag $(\varphi)$ and decrement factor (f) are important dynamic parameters to evaluate the heat storage capacity of a wall system. A heatwave has a specific amplitude and a specific wavelength. The wall system, as a thermal mass, reduces the amplitude of the heatwave. The time lag represents the time variance between the heatwave peak occurring outdoors and indoors. In addition, the decrement factor describes the amplitude ratio of the heatwave before and after passing through the wall. Literature review shows that assessing the time lag and decrement factor are considered among the most useful methods to determine the HVAC load [34-36].

Concerning the substantial impact of cooling load on thermal comfort in a fully air-conditioned building, optimizing thermal comfort and cooling load demand can be challenging for green buildings in a tropical climate. Particularly in Malaysia, green building index (GBI) platinum-certified office buildings should achieve maximum energy performance of $90 \mathrm{kWh} / \mathrm{m}^{2} /$ year but also provide thermal satisfaction for at least $80 \%$ of occupants [37]. The GBI is an environmental rating system tool in Malaysia, similar to the Leadership in Energy and Environmental Design (LEED) in the United State of America. Regard energy efficiency, Kwong and Adam [2] reviewed thermal comfort and energy efficiency in tropical climates, including in Malaysia, and indicated the importance of thermal investigation to optimize indoor air temperature and energy efficiency by using computational simulation tools. To address this challenge, in this field study, thermal investigation was integrated with predicting cooling energy demand using TETD for a GBI platinum-certified office building in the tropical climate of Malaysia. Thus, a comprehensive field study, including subjective investigation of thermal sensation vote (TSV) and objective measurement of thermal variables in the indoor built environment, is necessary. Besides optimizing thermal comfort based on energy efficiency, it is crucial to evaluate the amount of energy consumption regarding different setpoint temperatures to predict cooling load demand. As illustrated in Figure 1, this study aims to determine the optimum set-point of indoor air temperature for a GBI office building in Malaysia through the following steps:

1. Investigating the thermal quality of a GBI Platinum-certified office building in Malaysia through both objective and subjective measurements;

2. Comparing PMV (Fanger's PMV-PPD model) with TSV;

3. Calculating the amount of cooling energy demand with the TETD method for various neutral indoor set-point temperatures;

4. Determining the optimum indoor air temperature based on occupant comfort and cooling energy demand.

To achieve the objectives of this study, the paper is structured as follows: an introduction is given in Section 1; applied methodology explaining subjective and objective measurement and TETD method construction to calculate cooling energy demand is explained in Section 2, followed by results and discussion of findings in Section 3. Lastly, Section 4 summarizes and concludes this paper.

\section{Green Building Index}

GBI was developed in 2009 by the Malaysian Institute of Architect and the Association of Consulting Engineers Malaysia (ACEM) [37]. GBI awards buildings based on six assessment criteria, which are: Energy Efficiency, Indoor Environment Quality, Sustainable Site Planning and Management, Material and Resources, Water Efficiency and Innovation [37]. Based on the total points gained from assessment criteria, buildings are awarded and classified into four categories as Platinum, Gold, Silver, Certified respectively, in which Platinum is the highest classification [37]. 


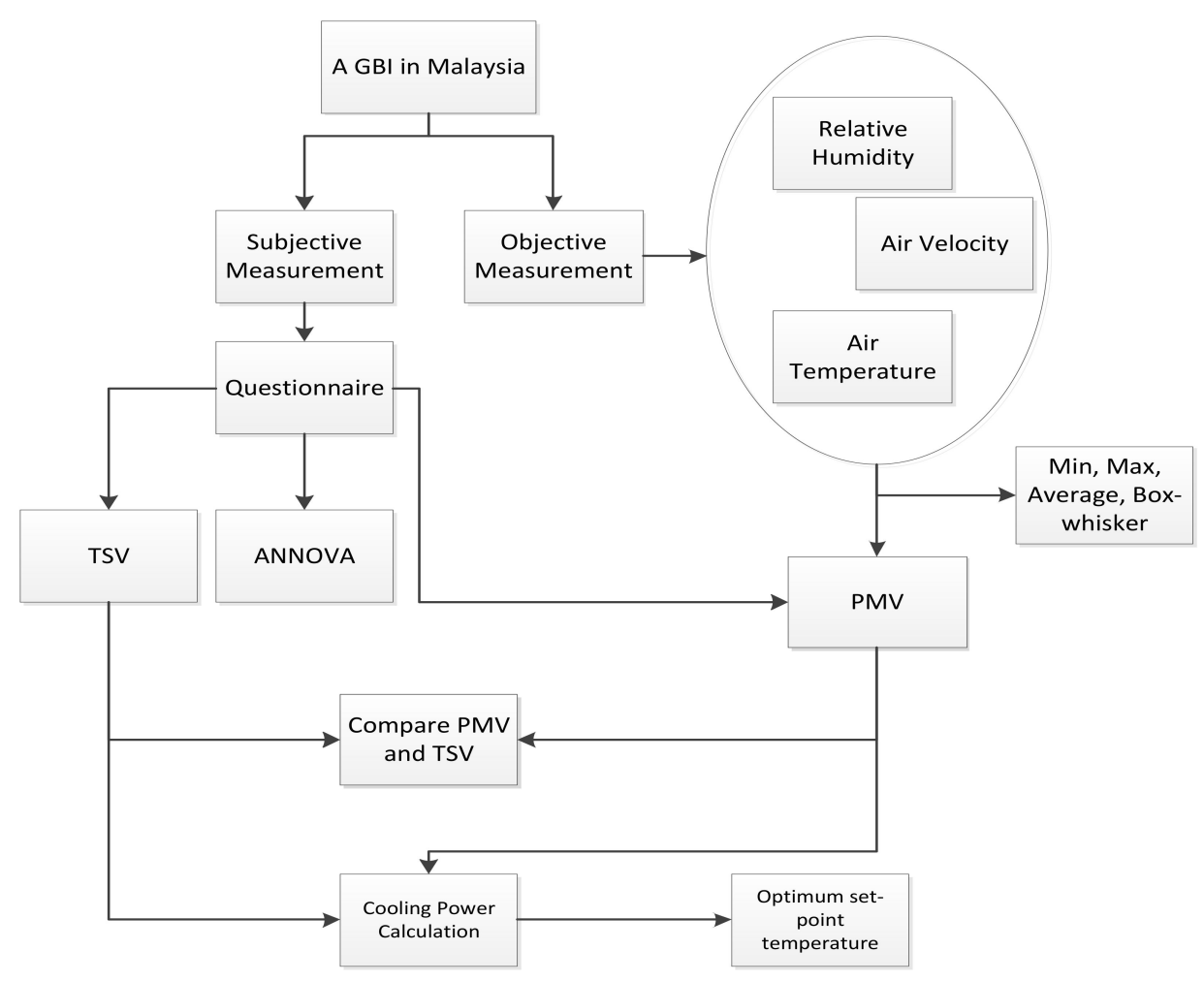

Figure 1. Analytical framework of thermal optimization.

\section{Materials and Methods}

A case study approach was adopted to achieve a comprehensive interpretation of thermal quality in a Platinum-certified office building. This kind of research emphasizes the few events or conditions and their interactions to provide a thorough interpretation of the events [38]. This study included an investigation of thermal sensation vote (TSV), thermal quality effect on occupant's satisfaction, occupant's characteristic effect on thermal satisfaction for gender, age, location, and type of office, and thermal quality effect on perceived productivity. In addition, based on the investigation, the cooling load demand was optimized according to different neutral indoor temperatures using heat transfer equations in a transient condition.

The case study was selected based on several criteria: being an office building, Platinum GBI certificate, located in Kuala Lumpur, and in an operational phase for a minimum of two (2) years. Figures 2 and 3 illustrate the site plan and plan layout of the selected office building, respectively.

\subsection{Office Building Characteristics}

The selected building is in Kuala Lumpur, Malaysia. The office building is Platinumcertified by GBI under the Noun-Residential New Construction (NRNC) category. Key data of the building is explained in Table 1. The underfloor air distribution (UFAD) system provides cooling and ventilation. UFAD is a system for providing ventilation by raising the floor and applying an air plenum below it to distribute the conditioned air through vents or diffusers where the vents can be controlled to adjust the air outlet [39]. Generally, there are limited opportunities for occupants to adjust the thermal condition using an environmental control system. The ability to control the floor vents does not have a huge impact on indoor thermal condition. In addition, there are no operable windows to adjust the thermal and air quality with natural ventilation. 


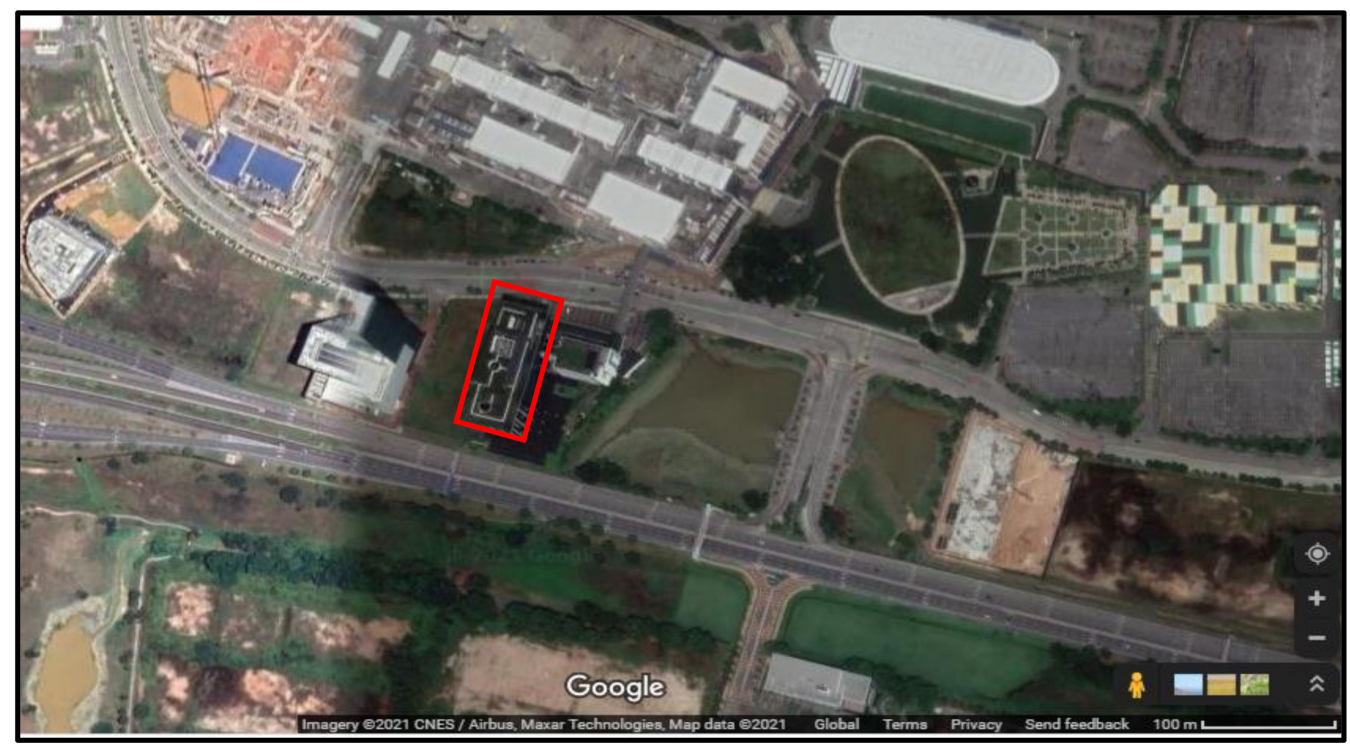

Figure 2. Location of the case study building.

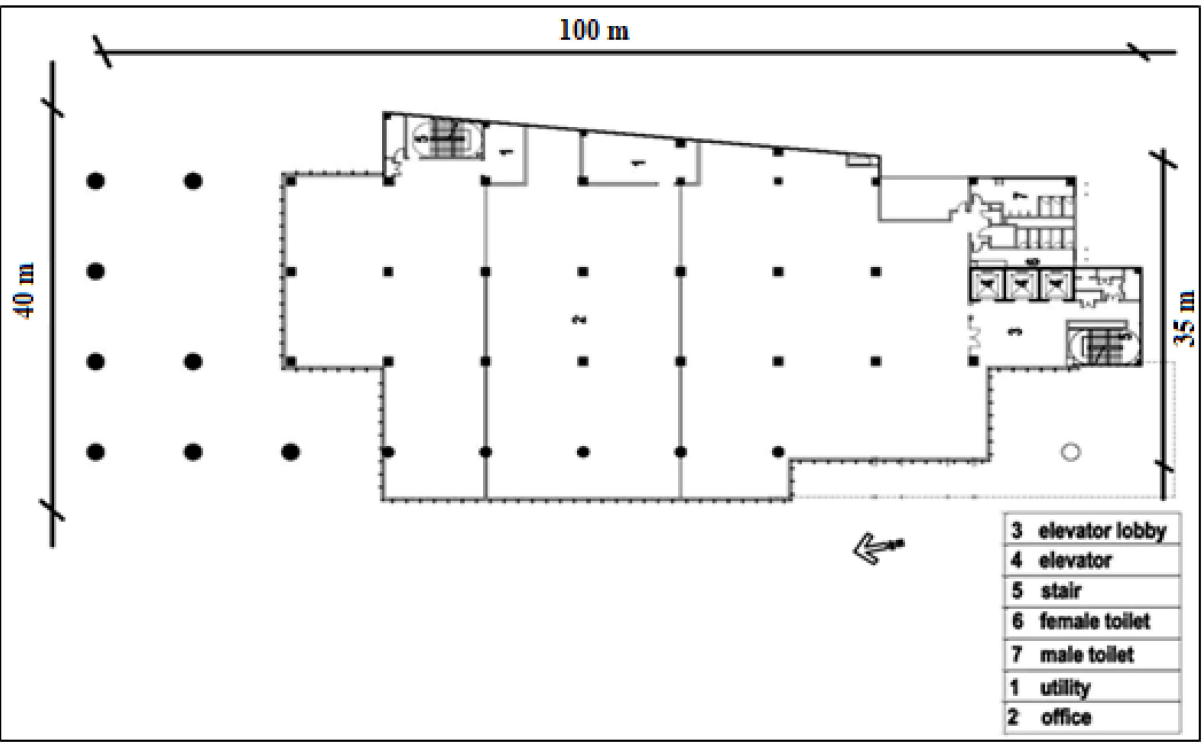

Figure 3. Plan layout of the selected office building-open plan office.

Table 1. Key data of the case study building.

\begin{tabular}{cc}
\hline Characteristics & Details \\
\hline Occupant possession & 2014 \\
No. story & 9 \\
Gross floor area & $33,798 \mathrm{~m}^{2}$ \\
Net floor area & $14,087 \mathrm{~m}^{2}$ \\
Structure & Steel reinforced concrete (SRC) \\
Façade finishing & Double glass curtain wall \\
Access to public transport & Bus \\
Air conditioning system & Underfloor Air Distribution (UAFD) \\
Underfloor vents & Yes \\
\hline
\end{tabular}


Table 1. Cont.

\begin{tabular}{cc}
\hline Characteristics & Details \\
\hline Floor/roof radiant cooling & No \\
Adjustable vents & Yes \\
Operable windows & No \\
Lighting type & Fluorescent, Personal LED \\
Window blind, roller shade, fixed & Yes \\
shading system & About 55\% \\
Window to wall ratio (WWR) & No \\
Exterior shades & No \\
Interior separators & Yes \\
Atrium & 250 \\
Courtyard & $60-100$ \\
Occupants' capacity & 2014 \\
Employees /occupants & Medium-density fibreboard (MDF), and Glass \\
Year of GBI certificate &
\end{tabular}

\subsection{Thermal Quality Monitoring}

Indoor thermal quality was investigated with full-scale (objective) measurement and occupant survey (subjective measurement).

\subsubsection{Full-Scale Measurement}

To perform the full-scale measurement, the subjective floors including open offices were monitored from 21 May to 10 August 2019. During this period, the indoor thermal temperature was monitored using six sets of environmental loggers adjusted to $5 \mathrm{~min}$ interval sampling. However, data extracted from loggers were limited to the building's operational hours from 8:00 a.m. to 6:00 p.m. Average values of the thermal variables were calculated using loggers' outputs. For instance, data logged at 1:00 p.m. from all sensors were accumulated and divided by six to produce an average value for 1:00 p.m. This way, a daily average from 8:00 a.m. to 6:00 p.m. for each variable was created. Then, the average value for the variable was calculated according to the daily average spectrum.

Thermal parameters such as air temperature $\left(T_{a}\right)$, relative humidity $(R H)$ and air velocity were measured with calibrated instruments (Figure 4c). In addition, regarding mean radiant temperature, the difference between indoor air temperature and mean radiant temperature was negligible under moderate outdoor conditions. Thus, the mean radiant temperature can be assumed equal to the indoor air temperature [40-42]. As illustrated in Figure $4 a, b$, instruments were installed on a pole close to the occupants' workstations at a height of approximately $1.1 \mathrm{~m}$ above the finished floor, following ISO 16000-1 [43]. To avoid the radiative temperature effect on devices, $0.8 \mathrm{~m}$ horizontal distance with other surfaces was applied to the devices' location. Table 2 summarises loggers' specifications.

Table 2. Specification of instruments.

\begin{tabular}{|c|c|c|}
\hline IEQ Variable & Environmental Logger & Range and Accuracy \\
\hline Air temperature & \multirow{2}{*}{$\begin{array}{c}\text { HOBO-U12-012 } \\
\text { (Manufactured by Onest, data logger) }\end{array}$} & $\begin{array}{c}\text { between }-20 \text { to } 70{ }^{\circ} \mathrm{C} \\
\text { accuracy } \pm 0.35{ }^{\circ} \mathrm{C} \text { from } 0 \text { to } \\
50{ }^{\circ} \mathrm{C}\end{array}$ \\
\hline Relative humidity & & $\begin{array}{l}\text { between } 5 \% \text { and } 95 \% \text { RH with } \\
\quad \text { an accuracy of } \pm 2.5 \%\end{array}$ \\
\hline Air velocity & $\begin{array}{c}\text { T-DCI-F900-S-O }{ }^{\text {a }} \\
\text { (Connected to HOBO-U12-012 as an } \\
\text { external sensor, manufactured by } \\
\text { Onest) }\end{array}$ & $\begin{array}{c}\text { Accuracy greater than } 10 \% \text { of } \\
\text { the reading or } \pm 0.05 \mathrm{~m} / \mathrm{s} \text { or } \\
1 \% \text { full scale }\end{array}$ \\
\hline
\end{tabular}




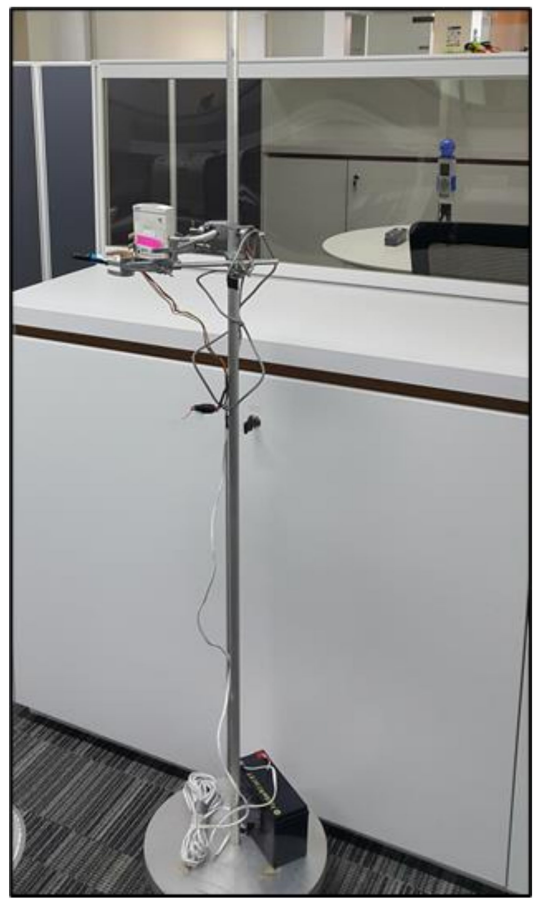

(a)

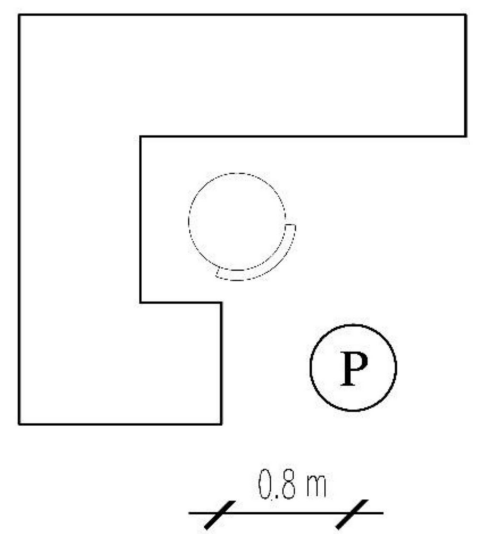

(b)

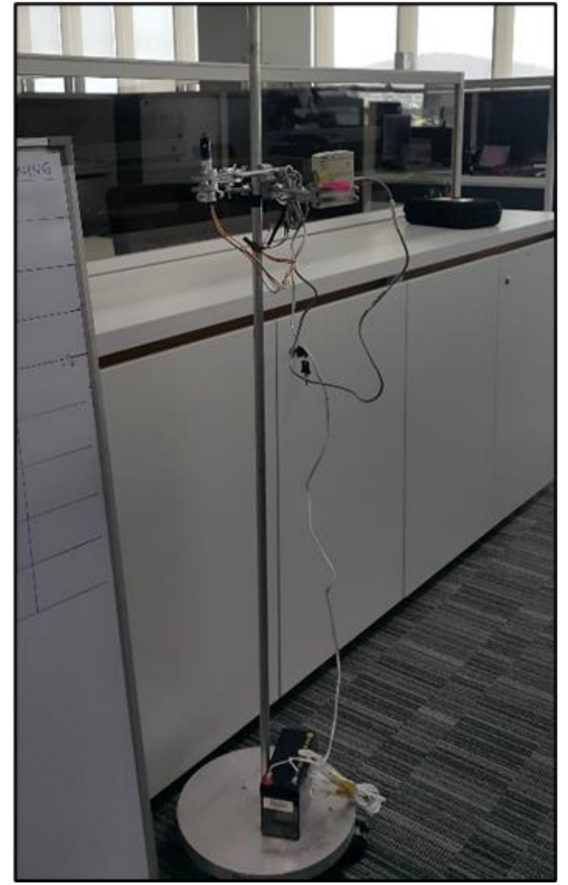

(c)

Figure 4. Examples of installed instruments. (a) Portable pole with loggers; (b) sample of pole location close to the workstation; (c) air temperature, air velocity, $\mathrm{RH}$ measurement.

\subsubsection{Occupant's Survey}

A paper-based questionnaire survey was conducted within the full-scale measurement by 2 July. The occupants were informed about the survey $24 \mathrm{~h}$ earlier. In addition, participating in the survey was optional. On the survey day, the questionnaires were distributed to occupants by the start of working hours and collected from their tables after working hours. Many believe this method is the most effective and best systematic technique of investigation to explore and examine mutual interactions between the building and occupants' needs [44-46]. Items in the questionnaire were measured using seven scale points following ASHRAE Standard 55 [15]. The summary of information collected with the questionnaire is presented Table 3.

Table 3. Information collected by questionnaire survey.

\begin{tabular}{cc}
\hline Category & Question \\
\hline Background information & $\begin{array}{c}\text { Age, Sex, Years of working in the building, Type of the } \\
\text { working office, Sitting near a window }\end{array}$ \\
\hline Thermal comfort & Overall Thermal comfort \\
& Temperature cold-hot \\
Temperature stable-various \\
Air dry-humid
\end{tabular}

Fifty-three valid respondents were collected from 81 distributed questionnaires. The uncompleted questionnaires were considered invalid. According to Cochran [47], the sample size and response rate came with a 95\% confidence level and $8 \%$ error of the building population. Females accounted for $47 \%$ and males at $53 \%$ of the responses. In addition, $51 \%$ and $49 \%$ reported ages of 30 years or above and under 30 years, respectively. Only $34 \%$ reported sitting near windows. Further information on the distribution of the respondents, including a reply to work experience in the building and type of the work office, is summarized in Table 4. 
Table 4. Background and demographic of valid respondents.

\begin{tabular}{cccc}
\hline & & \multicolumn{2}{c}{$\begin{array}{c}\text { Case Study } \\
\text { Building }\end{array}$} \\
\cline { 3 - 4 } & & $\mathbf{N}$ & \% \\
\hline \multirow{2}{*}{ Sex } & Female & 25 & 47 \\
& Male & 28 & 53 \\
\hline \multirow{2}{*}{ Age } & Under 30 & 26 & 49 \\
& 30 and above & 27 & 51 \\
\hline \multirow{2}{*}{ Work experience in building } & Less than a year & 20 & 38 \\
& A year or more & 33 & 62 \\
\hline \multirow{2}{*}{ Type of the work office } & Normally occupied by 1 & 8 & 15 \\
& Shared with 1 other & 0 & 0 \\
& Shared with 2-4 others & 22 & 41 \\
\hline \multirow{2}{*}{ Do you sit next to a window? } & Shared with 5-8 others & 15 & 29 \\
& Shared with more than 8 others & 8 & 15 \\
\hline
\end{tabular}

\subsection{Fanger's $P M V-P P D$}

Fanger's PMV-PPD model was developed to illustrate thermal sensations in sevenpoint scales resulting from numerous experiments on human subjects in several environments [16]. Fingers' model provides a set of equations to compute predicted mean vote (PMV) and predicted percentage dissatisfied (PPD).

Fanger's PMV-PPD model was employed in this study to: (1) compare PMV with TSV in a tropical climate and (2) suggest neutral temperatures as an input for energy usage calculation. To compute PMV and PPD, air temperature $\mathrm{T}_{\mathrm{a}}\left({ }^{\circ} \mathrm{C}\right)$, relative humidity $\mathrm{R}_{\mathrm{h}}(\%)$, and air velocity $\mathrm{V}_{\mathrm{a}}\left(\mathrm{ms}^{-1}\right)$ are measured directly. Occupants' clothing value (Clo) was observed to be typical working indoor appearances, such as pants and shirts. Per the usual office workload, working on a desk with a computer was observed for metabolic rate (met).

\subsection{Cooling Power Calculation}

Cooling power calculation was applied to this study to: (1) predict energy usage for different neutral air temperatures and (2) correlate energy usage with thermal satisfaction for a tropical condition. The cooling power was calculated for the baseline model and the other models with different indoor air temperatures. For this study, all boundaries were considered solid except for air temperature.

The amount of energy consumption for cooling was directly affected by outdoor temperature [48]. The geographic location of Kuala Lumpur is at latitude $3.13^{\circ} \mathrm{N}$ and longitude $101.68^{\circ}$ E. Kuala Lumpur's tropical climate is hot and humid. A ten-year period shows that outdoor temperatures of Kuala Lumpur from May to August are relatively uniform, with typical temperatures between 25.9 and $27.3{ }^{\circ} \mathrm{C}$ (Figure 5). 


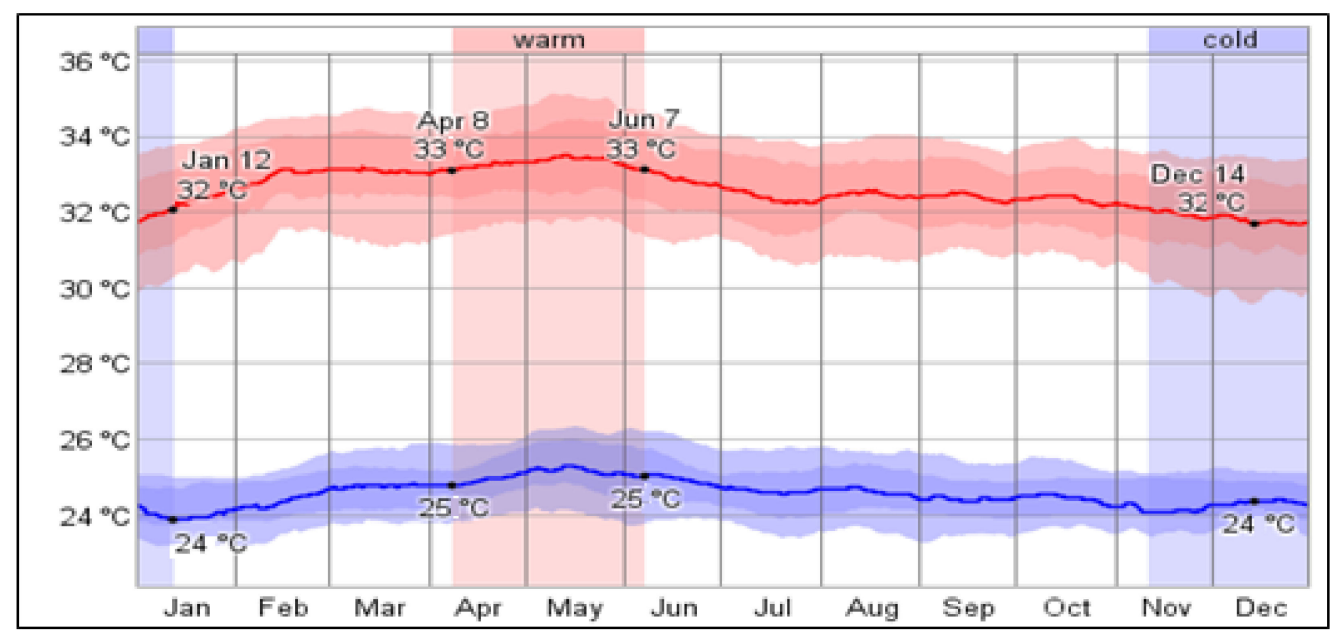

Figure 5. Daily average low and high temperatures with percentile bands Adapted with permission from ref. [49], 2021, ELSEVIER LICENSE.

Microclimate data were collected from Meteonorm 7 software, which is a comprehensive climatological database [50]. The collected data were used to investigate the effect of outdoor conditions on the indoor environment with Spearman's rho correlation test. The result of the test showed a positively strong significant correlation between indoor and outdoor air temperature fluctuation $(\mathrm{r}=0.905 ; p<0.05)$ as shown Table 5 . Thus, outdoor air temperature is a significant predictor of indoor air temperature $\left(\mathbb{R}^{2}=0.967 ; p<0.05\right)$. The total equivalent temperature difference method (TETD) was applied to calculate the cooling load. The total heat transfer coefficient, time lag, and decrement factors should be considered for cooling load calculation based on TETD. The governing equations are explained in the following sections.

Table 5. Correlation coefficient between indoor and outdoor temperatures.

\begin{tabular}{cc}
\hline Indoor Air Temperature & Outdoor Air Temperature \\
\hline Correlation Coefficient & $0.905^{* *}$ \\
$p$ value & 0.000 \\
$\mathrm{R}^{2}$ & 0.967 \\
\hline
\end{tabular}

** Correlation is significant at the level of $p<0.01$ level (two-tailed).

\subsubsection{Governing Equations for Cooling Load (Q)}

The internal cooling load was not constant and changed during the day due to changing the outdoor condition and thermal mass phenomena of building envelopes [51]. The TETD is a useful method to calculate the amount of external cooling load [52]. The following equation was applied to determine the amount of required cooling power caused by heat transfer through conduction:

$$
\mathrm{Q}=\text { U.A. (TETD) }
$$

and TETD is:

$$
\mathrm{TETD}=\mathrm{T}_{\mathrm{sa}}-\mathrm{T}_{\mathrm{i}}+\mathrm{f}\left(\mathrm{T}_{\mathrm{sa}, \varnothing}-\mathrm{T}_{\mathrm{sa}}\right)
$$

where $\mathrm{U}$ is thermal transmittance $\left(\mathrm{W} / \mathrm{m}^{2},{ }^{\circ} \mathrm{C}\right)$, A is the heat transfer area $\left(\mathrm{m}^{2}\right), \mathrm{T}_{\mathrm{sa}}$ is the daily average sol-air temperature $\left({ }^{\circ} \mathrm{C}\right), \mathrm{T}_{\mathrm{i}}$ is the design indoor air temperature $\left({ }^{\circ} \mathrm{C}\right), \mathrm{f}$ is decrement factor, and $\mathrm{T}_{\mathrm{sa}, \varphi}$ is the sol-air temperature for time lag hours ago $\left({ }^{\circ} \mathrm{C}\right)$. The sol-air temperature is an outdoor variable, which is needed to calculate cooling load. This variable is based on both radiation and convection to predict the heat gain through exterior surfaces, and it is calculated using Equation (3): 


$$
\mathrm{T}_{\mathrm{sa}}(\mathrm{t}) \frac{\mathrm{T}_{\max }-\mathrm{T}_{\min }}{2} \operatorname{Cos}\left(\frac{2 \pi \mathrm{t}}{\mathrm{P}}\right)+\frac{\mathrm{T}_{\max }+\mathrm{T}_{\min }}{2}
$$

2.4.2. Governing Equations for Total Heat Transfer Coefficient (U-Value), Time Lag $(\varphi)$, and Decrement Factor (f)

These parameters are dependent on thermo-physical properties of the building envelope. In addition, the total heat transfer coefficient (U-value) of an envelope is directly related to its thermal resistance, which is calculated through the following equation:

$$
\mathrm{U}=\frac{1}{\mathrm{R}_{\mathrm{t}}}
$$

The sol-air temperature for time lag hours ago $\left(\mathrm{T}_{\mathrm{sa}, \varphi}\right)$ is calculated using the following equation:

$$
\mathrm{T}_{\mathrm{sa}, \varnothing}(\mathrm{t})=\mathrm{T}_{\mathrm{av}}+|\mathrm{T}| \operatorname{Cos}(\omega \mathrm{t}+\varphi)
$$

Conversely, based on EN ISO 13786 [53], the heat transfer matrix can be defined as:

$$
\mathrm{Z}=\left(\begin{array}{l}
\mathrm{T}_{2} \\
\mathrm{q}_{2}
\end{array}\right)=\left(\begin{array}{ll}
\mathrm{Z}_{11} & \mathrm{Z}_{12} \\
\mathrm{Z}_{21} & \mathrm{Z}_{22}
\end{array}\right)\left(\begin{array}{l}
\mathrm{T}_{1} \\
\mathrm{q}_{1}
\end{array}\right)
$$

where $T_{1}$ and $T_{2}$ are temperatures in situations one and two, respectively. $q_{1}$ and $q_{2}$ are heat flux in situation one and two, respectively. In addition, the matrix elements can be calculated as follow:

$$
\begin{gathered}
\mathrm{Z}_{11}=\mathrm{Z}_{22}=\cosh (\alpha) \cos (\alpha)+\mathrm{j} \sinh (\alpha) \sin (\alpha) \\
\mathrm{Z}_{12}=-\frac{\delta}{2 \mathrm{k}}\{\sinh (\alpha) \cos (\alpha)+\cosh (\alpha) \sin (\alpha)+\mathrm{j}[\cosh (\alpha) \sin (\alpha)-\sinh (\alpha) \cos (\alpha)]\} \\
\mathrm{Z}_{21}=-\frac{\delta}{\mathrm{k}}\{\sinh (\alpha) \cos (\alpha)-\cosh (\alpha) \sin (\alpha)+\mathrm{j}[\cosh (\alpha) \sin (\alpha)+\sinh (\alpha) \cos (\alpha)]\}
\end{gathered}
$$

where $\alpha$ is defined as the ratio of the thickness to the penetration depth:

$$
\alpha=\frac{\mathrm{d}}{\delta}
$$

and the periodic penetration is calculated by using the following equation:

$$
\delta=\sqrt{\frac{\mathrm{k} \cdot \tau}{\pi \cdot \rho \cdot \mathrm{C}}}
$$

where $\mathrm{k}$ is thermal conductivity $(\mathrm{W} / \mathrm{m} . \mathrm{K}), \tau$ is period of variations $(\mathrm{s}), \rho$ is density $\left(\mathrm{kg} / \mathrm{m}^{3}\right)$, and $C$ is the specific heat capacity $(\mathrm{J} / \mathrm{kg} . \mathrm{K})$. It should be noted that all these thermal parameters as well as thickness are known based on building materials used in this case. Thus, the elements of matrix were calculated based on Equations (7) to (9).

As a result, the heat transfer matrix from outside to the inside is:

$$
\mathrm{Z}_{\mathrm{out}-\mathrm{in}}=\mathrm{Z}_{\mathrm{s} 2} \mathrm{Z} \mathrm{Z}_{\mathrm{s} 1}
$$

where, $Z_{\mathrm{s} 2}, Z_{\mathrm{s} 1}$ are the heat transfer matrices of inside and outside based on convection and radiation values. ISO 6946 described the standard value for $R_{s}$ [54].

$$
\mathrm{Z}_{\mathrm{s}}=\left(\begin{array}{cc}
1 & -\mathrm{R}_{\mathrm{s}} \\
0 & 1
\end{array}\right)
$$

Finally, the time lag and decrement factors are calculated as follow: 


$$
\begin{gathered}
\varphi=\frac{\tau}{2 \pi} \arg \mathrm{Y}_{12} \\
\mathrm{f}=\frac{\left|\mathrm{Y}_{12}\right|}{\mathrm{U}}
\end{gathered}
$$

When the $\mathrm{Y}_{12}$ is the periodical thermal transmittance as a function of the heat transfer matrix element $\left(Z_{12}\right.$ of $Z_{\text {out-in }}$ matrix):

$$
\mathrm{Y}_{12}=-\frac{1}{\mathrm{Z}_{12}}
$$

\subsection{Data Analysis}

Samples collected by environmental equipment and information extracted from questionnaires were utilized as follows:

- Full-scale measurement: a daily average chart was depicted. The minimum, maximum and average and variance of each variable were identified. Charts were drafted in a line and box-whisker plot with Microsoft Excel. Explanatory information obtained in this step was used as input for Fanger's PMV-PPD model and energy usage calculation.

- $\quad$ Statistical analysis: statistical package for social science (SPSS)-IBM SPSS statistics 24was employed to perform descriptive, frequency, one-way ANOVA, and regression.

- Cooling load design: the heat transfer through the building envelope was simulated using Energy 3D. The transient heat transfer equations were applied in Python to calculate time lag and decrement factor.

\section{Results and Discussion}

A critical analysis of collected data was carried out and the results are discussed in three sections as objective measurement, subjective measurement, and optimum temperature. The objective measurement represents the results of the analysis for thermal measurement and discusses them following similar studies or standards. The results of the survey analysis indicating occupant's thermal feedbacks and related analysis from the survey are given in the subsection of subjective measurement and have been discussed. The subsection suggests an optimum temperature to enhance thermal satisfaction and energy efficiency.

\subsection{Objective Measurement}

\subsubsection{Air Temperature}

Figure 6 shows the daily average air temperature (DAAT). Overall, DAAT shows a decrease during working hours, although the reduction is not significant. During this time, DAAT shows a low variance ranging from 23.6 to $24{ }^{\circ} \mathrm{C}$ with a mean of $23.8{ }^{\circ} \mathrm{C}$ (Figure $6 \mathrm{~b}$ ). Low air temperature variance is an indication of a successfully applied mechanism to control indoor air temperature such as isolations that stop outdoor heat penetration to the indoor environment, resulting in a low air temperature variance. DAAT started at $24^{\circ} \mathrm{C}$ and finished at $23.8^{\circ} \mathrm{C}$ by 18:00 (Figure 6a).

Air temperature samples were collected from different floors used for DAAT. To make sure there was no significant difference between collected samples of each floor, KruskalWallis one-way ANOVA test was conducted. As shown in Table 6, statistically, there is a significant difference $(p<0.05=0.000)$ among mean air temperatures across floors. The main reason for this difference was observed to be occupant density, in which the fifth floor included a significantly higher number of occupants. In addition to occupant density, occupant control over the air vents could be another reason for this significant difference. 


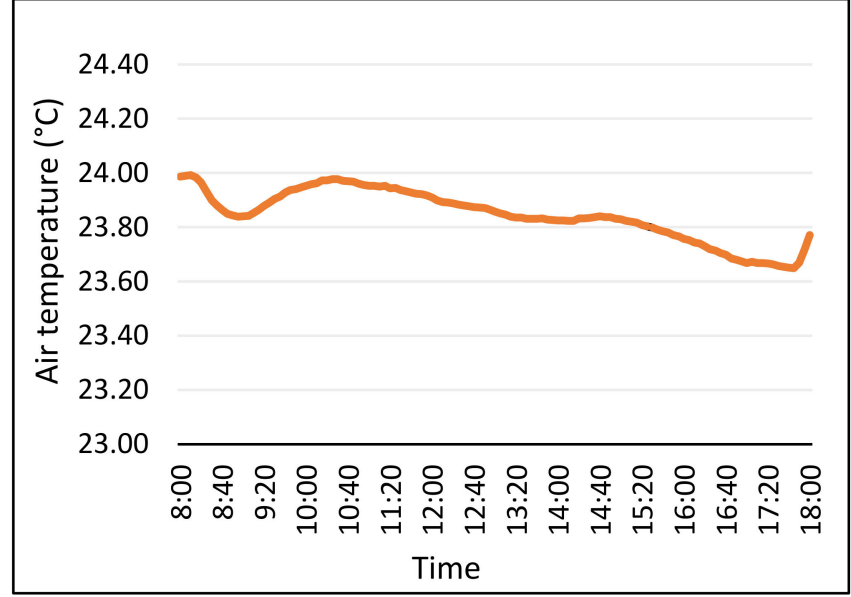

(a)

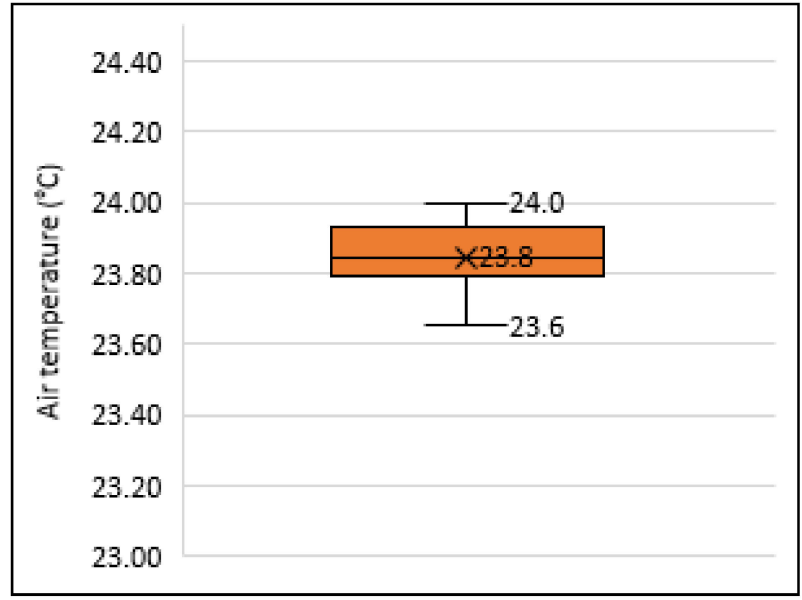

(b)

Figure 6. Daily average of air temperature (DAAT) and distribution. (a) DAAT; (b) distribution.

Table 6. Independent Kruskal-Wallis Test of mean air temperatures across floors.

\begin{tabular}{cc}
\hline Building & $p$ Value \\
\hline Case study building & $0.000 *$ \\
\hline *Significant if $p<0.05$.
\end{tabular}

In general, air temperature is maintained around $24^{\circ} \mathrm{C}$, which is considered as an appropriate range according to MS 1525 [11]. Dry bulb temperature is recommended to be in a range of 24 to $26^{\circ} \mathrm{C}$ with a minimum of $23^{\circ} \mathrm{C}$ for office buildings [11]. ASHRAE Standard 55 [15] also suggests an upper limit of $27.2{ }^{\circ} \mathrm{C}$ (with 0.5 clo and $50 \% \mathrm{RH}$ ) to provide a thermally comfort zone for $80 \%$ of occupants. In addition, low air temperature is suggested to be associated with health issues such as respiratory disease and asthma [55].

\subsubsection{Relative Humidity}

Daily average relative humidity (DARH) is depicted in Figure 7a. Overall, RH reduced during building operation hours, with a considerable reduction in early hours. The early drop was due to the HVAC system operation schedule working between 8:00 and 18:00. The HVAC system was not operational outside of working hours, resulting in a rise of RH, and thus a drop in daily average RH can be seen by the start of working hours. The DARH started at $78 \%$ and reduced to $73 \%$ by $18: 00$. DARH ranged-without considering the outliners by the start of working hours-from $71 \%$ to $73 \%$, with a mean of $72 \%$ (Figure $7 \mathrm{~b}$ ).

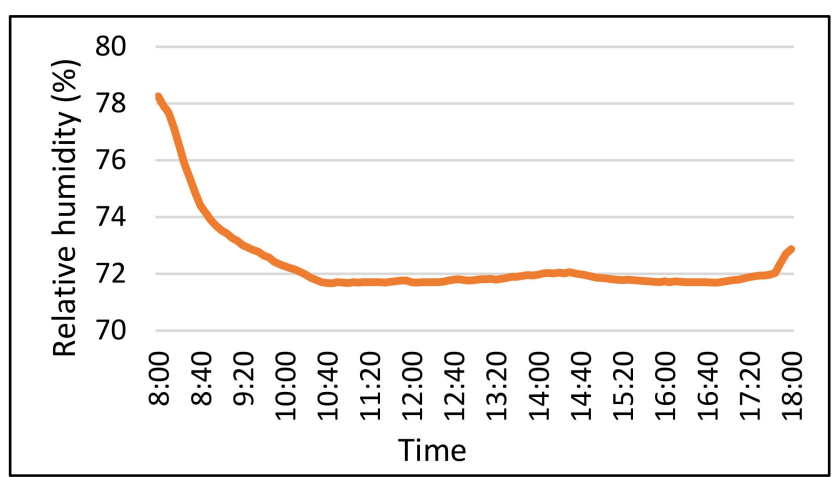

(a)

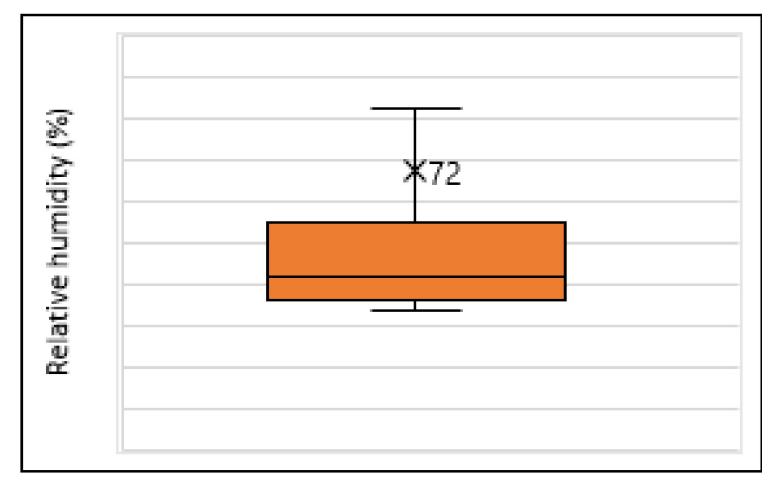

(b)

Figure 7. Daily average relative humidity (DARH) and distribution. (a) DARH; (b) distribution.

During the full-scale measurement, RH samples remained between $57 \%$ and $90 \%$. Malaysian standard MS 1525 [11] suggests a range of 50\% to $70 \%$ RH with an indication of 
not exceedingly more than $70 \%$ for office buildings. In this regard, average $\mathrm{RH}$ surpassed the suggested range. High humidity level was shown to have negative health effects for short-term exposure [56]. In addition, it is associated with bacteria, fungi, and virus growth in indoor environments [55].

\subsubsection{Air Velocity}

Figure 8a illustrates the daily average air velocity (DAAV). As mentioned in Section 2.2.1, air velocity is measured around the breathing area of a seated person during working hours. Holistically, DAAV shows a low and linear air velocity within the range from 0.04 to $0.06 \mathrm{~m} / \mathrm{s}$, with a mean of $0.05 \mathrm{~m} / \mathrm{s}$ during working hours (Figure $8 \mathrm{~b}$ ). There is no vestige of any surprising increase or decrease. In addition, during monitoring, 0.03 and $0.09 \mathrm{~m} / \mathrm{s}$ were the minimum and maximum data logged.

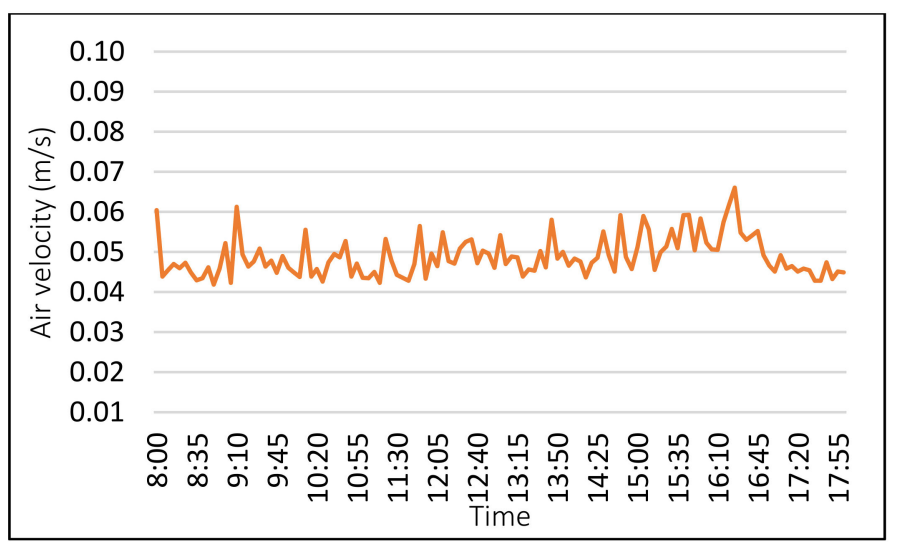

(a)

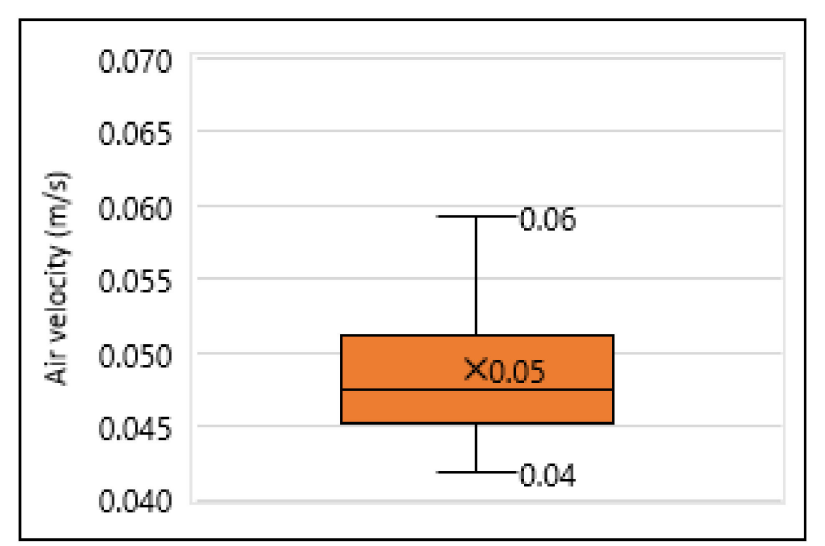

(b)

Figure 8. Daily average air velocity (DAAV) and distribution. (a) DAAV; (b) distribution.

Although the pattern observed in Figure 8a seems to shockingly change over time in airspeed, the low variance of $0.02 \mathrm{~m} / \mathrm{s}$ was insignificantly felt by occupants. Lechner [57] indicated that air velocity below $0.05 \mathrm{~m} / \mathrm{s}$ is notable by occupants. In addition, the maximum airspeed is suggested to be lower than $0.2 \mathrm{~m} / \mathrm{s}$ by various standards, as reviewed by Khovalyg, Kazanci, et al. [58]. Malaysian standard MS 1525 [11] suggested a range from $0.15-0.50 \mathrm{~m} / \mathrm{s}$ for air velocity. However, standards suggest that exceeding airspeed can be used in higher air temperatures $\left(25\right.$ to $26{ }^{\circ} \mathrm{C}$ above) to have a thermally indoor environment [58]. In office buildings, controllable vents by occupants are highly suggested in exceeding air velocities to prevent papers from blowing away from the desk.

Particularly for this study, the building is equipped with adjustable vents to distribute air from the underfloor; however, it was observed that most of the vents adjacent to workstations were closed by occupants, which resulted in low air velocity near the breathing area of a seated person. This was due to the cool air temperature in which higher air velocity extended the level of cool sensation for occupants [58]. Thus, higher air temperature is suggested to convince occupants to allow more air flow around the breathing zone. This is an important implication since air change rate or airspeed contributes to overall air quality by removing pollutants from indoor air and improving work performance [55].

\subsection{Subjective Measurement}

\subsubsection{Thermal Sensation Analysis}

A questionnaire survey was used to evaluate variables of thermal quality. To do so, variables were evaluated with a seven-point Likert scale under ASHRAE Standard 55 [15] from uncomfortable $(-3$ to -1$)$, neutral $(0)$ and comfortable $(+1$ to +3$)$. Figure 9 illustrates the distribution of the responses to overall comfort (a), thermal sensation vote (TSV) (b), temperature stability (c) and air humidity (d). Only a minority of occupants $(22.6 \%)$ reported overall comfort-mean vote of 0.07 -with thermal quality (Figure 9a). ASHRAE 
Standard 55 [15] suggests a minimum of $80 \%$ satisfaction from thermal quality, and the rate is critically lower in this building. The main reason for low satisfaction drives from a cool environment, as thermal sensation mean vote is -1.25 with $77.4 \%$ uncomfortable occupants (Figure 9 b). Besides cool feeling, most occupants $(81.1 \%)$ reported uncomfortable humid indoor air (Figure 9c). Both air temperature and relative humidity are significant variables contributing to thermal quality, which this building fails to satisfy in its occupants. A high RH level is also observed during monitoring of thermal quality (see also Figure 7). Regarding the stability of the air temperature, only a minority of occupants $(24.5 \%)$ reported unstable air temperature during the day. This result is followed by low variance of air temperature during full-scale measurement (see Figure 6). Overall, the reports indicate that a majority are dissatisfied with thermal quality. This thermal unsatisfaction has been reported by other studies in tropical climates, resulting in proposed models to increase thermal quality [59], of which Fanger's PMV model is one of the tools to predict thermal satisfaction to improve quality of the variables.

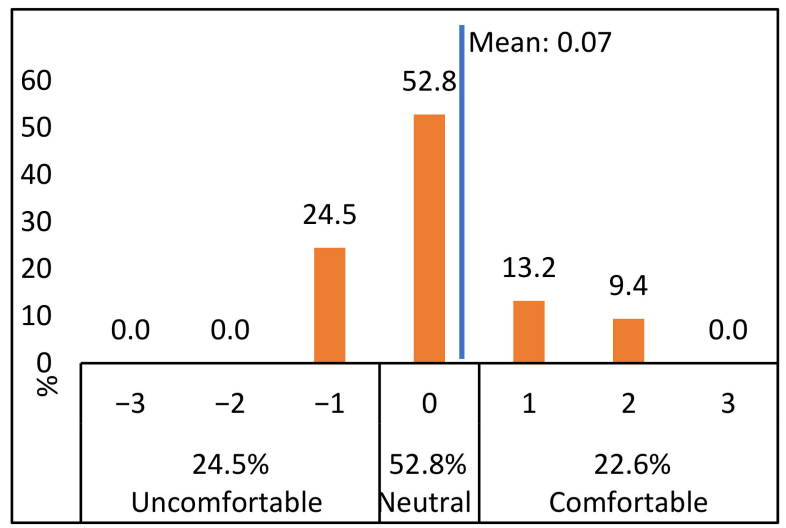

(a)

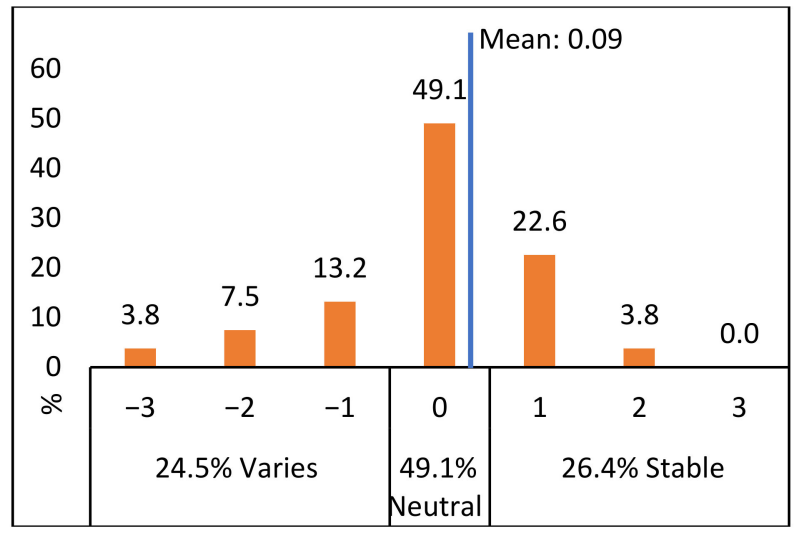

(c)

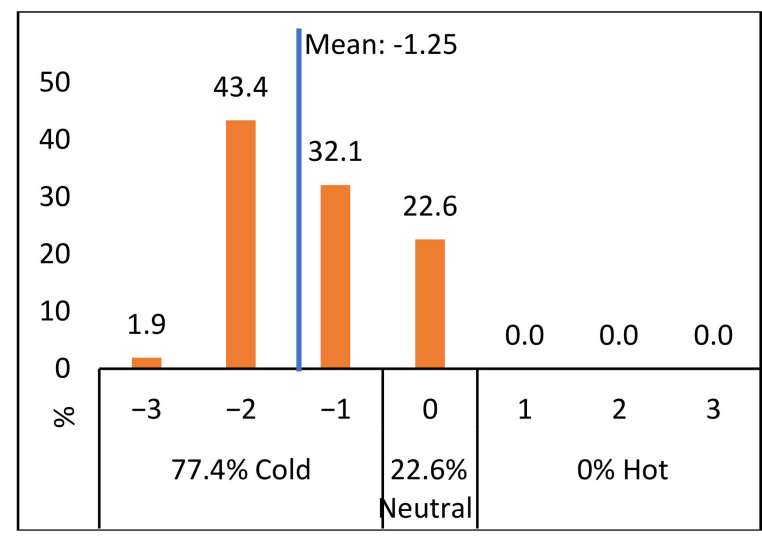

(b)

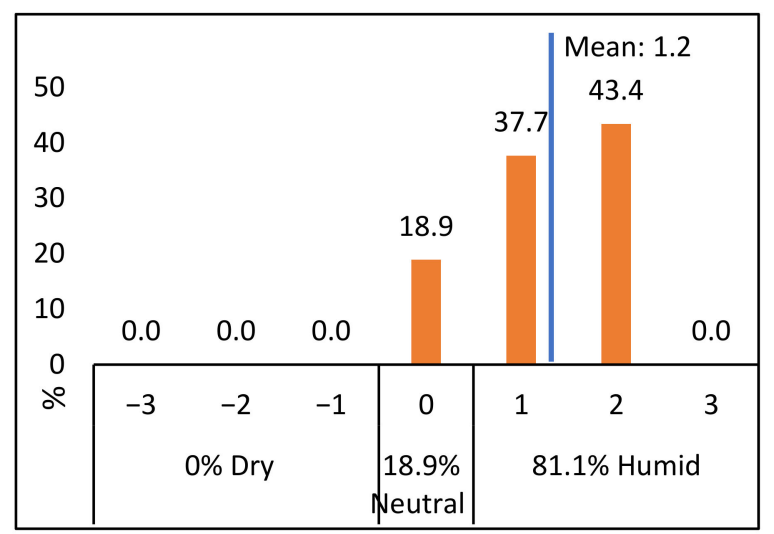

(d)

Figure 9. Frequency of occupants vote to thermal quality variables. (a) Overall thermal comfort; (b) thermal sensation vote; (c) temperature stability; (d) air humidity.

\subsubsection{Thermal Analysis Based on Occupant Characteristics}

Occupant responses for thermal variables were statistically analysed to determine whether there was a significant difference based on their characteristics. The characteristics were defined as age, gender, type of office, distance to a window, and work experience in building. $T$ test and one-way ANOVA analysis results showed that statistically there is no significant difference $(p>0.05)$ between most variables (Table 7). Indicating, occupant responses were not affected by their characters. The responses are statistically different regarding the distance from the window over thermal sensation in which those far from the window reported cooler feeling versus those near the window. In addition, the overall 
thermal sensation was different according to the occupant's office type. In this regard, occupants in shared offices with more than eight people reported the highest satisfaction in thermal quality, whereas occupants in rooms shared with 2 to 4 people reported the lowest satisfaction (mean vote 4.88 to 3.86). Regarding gender, although Maykot and Rupp [23] reported a statistical difference according to gender over thermal comfort in an office building in the tropical climate of Brazil, there was no statistical difference observed in the finding of this study.

Table 7. Impact of occupant characteristics on the perception of thermal variables.

\begin{tabular}{|c|c|c|c|c|c|c|c|c|c|c|c|c|c|}
\hline & & \multicolumn{2}{|c|}{ Age } & \multicolumn{2}{|c|}{ Gender } & \multicolumn{4}{|c|}{ Type of Office } & \multicolumn{2}{|c|}{ Near Window } & \multicolumn{2}{|c|}{$\begin{array}{c}\text { Work Experience in } \\
\text { Building }\end{array}$} \\
\hline & & $\begin{array}{l}\text { Under } \\
30\end{array}$ & $\begin{array}{c}\text { Above } \\
30\end{array}$ & Male & Female & Private & $2-4$ & $5-8$ & $\mathbf{N}>8$ & Yes & No & $\mathbf{N}<1$ Year & $N>1$ Year \\
\hline \multicolumn{2}{|l|}{$\%$} & $49 \%$ & $51 \%$ & $53 \%$ & $47 \%$ & $15 \%$ & $41 \%$ & $29 \%$ & $15 \%$ & $34 \%$ & $66 \%$ & $37 \%$ & $63 \%$ \\
\hline \multirow{3}{*}{$\begin{array}{l}\text { Overall } \\
\text { ther- } \\
\text { mal }\end{array}$} & $\mathrm{t}$ & \multirow{3}{*}{\multicolumn{2}{|c|}{$\begin{array}{c}-0.613 \\
51 \\
0.883\end{array}$}} & \multirow{3}{*}{\multicolumn{2}{|c|}{$\begin{array}{c}-2.334 \\
51 \\
0.073\end{array}$}} & \multirow{3}{*}{\multicolumn{4}{|c|}{$\begin{array}{c}\mathrm{F}=3.153 \\
52 \\
0.033 *\end{array}$}} & \multirow{3}{*}{\multicolumn{2}{|c|}{$\begin{array}{c}-0.118 \\
51 \\
0.150\end{array}$}} & \multirow{3}{*}{\multicolumn{2}{|c|}{$\begin{array}{c}-0.486 \\
51 \\
0.08\end{array}$}} \\
\hline & $\mathrm{df}$ & & & & & & & & & & & & \\
\hline & Sig & & & & & & & & & & & & \\
\hline \multirow{3}{*}{$\begin{array}{l}\text { Thermal } \\
\text { sensa- } \\
\text { tion }\end{array}$} & $t$ & \multirow{3}{*}{\multicolumn{2}{|c|}{$\begin{array}{c}0.534 \\
51 \\
0.347\end{array}$}} & \multirow{3}{*}{\multicolumn{2}{|c|}{$\begin{array}{c}0.703 \\
51 \\
0.515\end{array}$}} & \multirow{3}{*}{\multicolumn{4}{|c|}{$\begin{array}{c}\mathrm{F}=0.670 \\
52 \\
0.574\end{array}$}} & \multirow{3}{*}{\multicolumn{2}{|c|}{$\begin{array}{c}-0.491 \\
51 \\
0.002 *\end{array}$}} & \multirow{3}{*}{\multicolumn{2}{|c|}{$\begin{array}{c}0.032 \\
51 \\
0.450\end{array}$}} \\
\hline & df & & & & & & & & & & & & \\
\hline & Sig & & & & & & & & & & & & \\
\hline \multirow{3}{*}{ Humidity } & $t$ & \multicolumn{2}{|c|}{-2.103} & \multicolumn{2}{|c|}{2.032} & \multicolumn{4}{|c|}{$F=1.891$} & \multicolumn{2}{|c|}{1.099} & \multicolumn{2}{|c|}{0.935} \\
\hline & $\mathrm{df}$ & \multicolumn{2}{|c|}{51} & \multicolumn{2}{|c|}{51} & \multicolumn{4}{|c|}{52} & \multicolumn{2}{|c|}{51} & \multicolumn{2}{|c|}{51} \\
\hline & Sig & \multicolumn{2}{|c|}{0.213} & \multicolumn{2}{|c|}{0.544} & \multicolumn{4}{|c|}{0.143} & \multicolumn{2}{|c|}{0.517} & \multicolumn{2}{|c|}{0.616} \\
\hline \multirow{3}{*}{ Stability } & $t$ & -0 & 502 & & 130 & & $\mathrm{~F}=$ & 125 & & & & & \\
\hline & $\mathrm{df}$ & & & & & & & & & & & & \\
\hline & Sig & & & & & & & & & & & & \\
\hline
\end{tabular}

* Significant if $p<0.05$.

\subsubsection{PMV and TSV}

Standards, such as the ASHRAE Standard 55 [15], provide guidelines to predict thermal comfort with the use of modes such as Fanger's PMV-PPD model. Comparisons of Fanger's PMV-PPD with thermal sensation mean vote have been performed in various studies [59-61]. This comparison is usually performed to localize and upgrade accuracy in Fanger's PMV-PPD predictions. For this study, a comparison was made to: (1) investigate the accuracy of Fanger's PMV-PPD prediction for fully air-conditioned office buildings in a tropical climate, and (2) it was utilized to suggest neutral air temperatures. Based on the findings from full-scale measurements, the PMV-PPD model was calculated as shown in Table 8.

The PMV was -0.17 , suggesting that the operational thermal condition complies with ASHRAE Standard 55 [15]. Thus, occupants should feel comfortable. However, PMV-PPD overestimated occupant thermal sensation, where TSV was -1.25 with a 1.8-unit difference in PMV prediction. ASHRAE Standard 55 [15] defined that the neutral thermal feeling for TSV is between -0.5 to +0.5 . Any mean TSV out of this range is considered as not comfortable, leading to a higher percentage of thermal dissatisfaction.

Figure 10 illustrates the gap between PMV and TSV. Although PMV stays in the comfort zone, the TSV is out of the acceptable range according to ASHRAE Standard 55 [15]. A similar gap between PMV and TSV has also been reported in several studies over time [62-66]. In addition, it has been reported that the difference between predicted and actual sensation can be as large as 1.3 units [67,68]. According to Maiti [63], the difference could be due to the tropical climate of Malaysia. Maiti [63] stated that PMV predicted a lower neutral temperature for occupants, while TSV estimated a wider comfort zone and a higher neutral temperature for occupants. In addition, it is suggested that subjects were more sensitive to coldness in comparison to a warmer temperature. Studies have indicated that personal adaptations, such as physiological, psychological, or behavioural thermoregulation, were not included in the PMV model as a parameter, which can be the reason for the PMV 
overestimation [69-71]. Thus, other implications need to be considered for providing a thermally comfortable environment, such as a regional thermology specification that is profoundly influenced by the local climatic condition, food, habitat, socio-culture, etc.

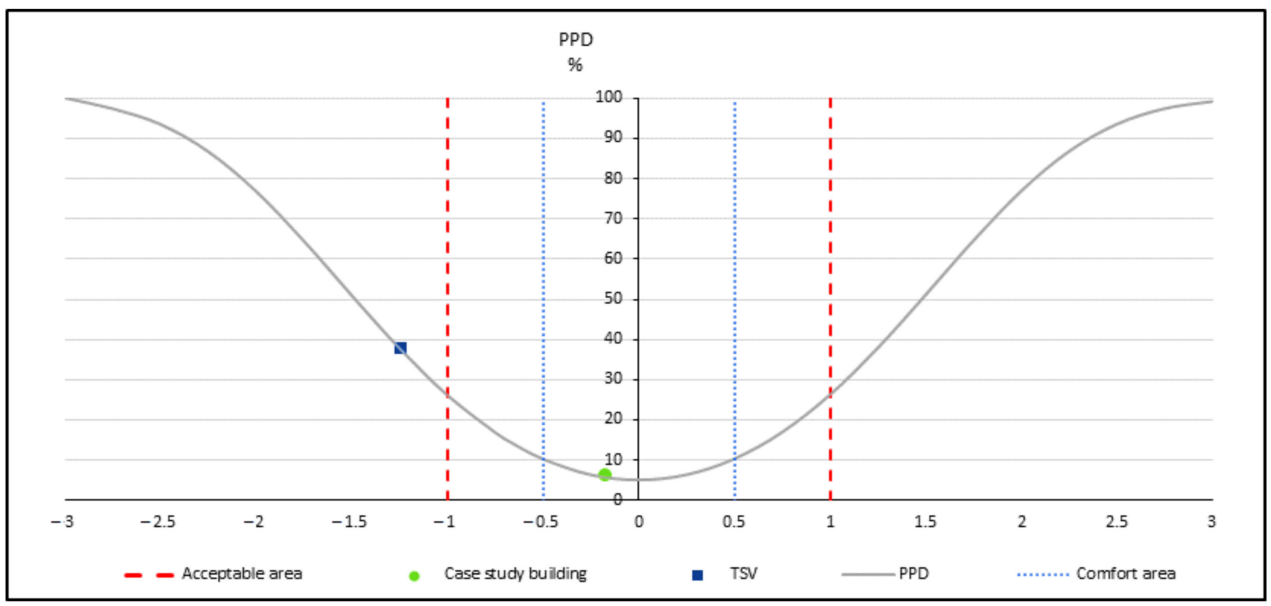

Figure 10. TSV versus Fanger's PMV-PPD model.

Table 8. Thermal comfort prediction-based on the average value measures.

\begin{tabular}{cccccccccc}
\hline & $\begin{array}{c}\mathbf{T}_{\mathbf{a}} \\
\left({ }^{\circ} \mathbf{C}\right)\end{array}$ & $\begin{array}{c}\mathbf{T}_{\mathbf{r}} \\
\left({ }^{\circ} \mathbf{C}\right)\end{array}$ & $\begin{array}{c}\mathbf{R}_{\mathbf{h}} \\
(\mathbf{\%})\end{array}$ & $\begin{array}{c}\mathbf{V}_{\mathbf{a}} \\
(\mathbf{m} / \mathbf{s})\end{array}$ & $\begin{array}{c}\mathbf{M}_{\mathbf{e}} \\
(\mathbf{m e t})\end{array}$ & $\begin{array}{c}\mathbf{C l} \\
(\mathbf{C l o})\end{array}$ & $\mathbf{P M V}$ & TSV & Thermal Sensation \\
\hline Case study Building & 23.8 & 23.8 & 72.35 & 0.05 & 1.1 & 0.57 & -0.17 & -1.25 & Neutral \\
\hline
\end{tabular}

Clo: for typical office type [72]; $\mathrm{M}_{\mathrm{e}}$ : normal activity of office typing [72]; $\mathrm{T}_{\mathrm{a}}=\mathrm{T}_{\mathrm{r}}[26,73]$.

\subsection{Temperature $\left(T_{\text {opt }}\right)$ Optimization}

The low set-point of the HVAC system causes extra power consumption and occupant comfort reduction. According to the literature, adjusting the thermostat temperature of the HVAC system is the best strategy to optimize thermal comfort [74]. Due to the critical condition of thermal quality based on the occupant's report indicating highly negative TSV, different models of neutral temperatures are suggested using the PMV-PPD model. The overestimation of Fanger's PMV model identified in this study is also considered to suggest neutral air temperatures. Air temperatures are measured as neutral if complying with the ASHRAE Standard 55 [15]. Air velocity and relative humidity are considered fixed items in the PMV model variables. Input data for the model is driven from the full-scale measurement result. Concerning negative TSV $(-1.25)$, neutral temperatures should be higher than the mean temperature $\left(23.8^{\circ} \mathrm{C}\right)$. To find neutral values, the input air temperature in the model can start at $24.0^{\circ} \mathrm{C}$, with a $0.5^{\circ} \mathrm{C}$ interval increase. This increase is limited to when the model fails to comply with SHRAE Standard 55 [15] and/or EN 16798-1 [14].

Table 9 presents PMV-PPD results for different temperatures. Model 0 predicts PMVPPD based on real-world data $\left(\approx 24.0^{\circ} \mathrm{C}\right)$. As shown in Table 9, Models 1, 2 and 3 comply with ASHRAE Standard 55 [15], indicating that, with an increase in air temperature from 24.0 to $25.5{ }^{\circ} \mathrm{C}$, occupants should feel comfortable with around 8\% PPD. Dissatisfied occupants should have a slightly warm sensation within Models 1 to 3 . This indicates a potential shift in occupants' thermal sensation vote from slightly cool to slightly warm. Model 4, with $26{ }^{\circ} \mathrm{C}$ air temperature, fails to comply with ASHRAE Standard 55 [15]. Temperatures higher than $26^{\circ} \mathrm{C}$ do not comply with standards, which can predict a high percentage of unsatisfied occupants. In addition, a temperature of above $26{ }^{\circ} \mathrm{C}$ is reported to associate with lower productivity in office buildings [58]. 
Table 9. PMV-PPD for different neutral temperatures.

\begin{tabular}{cccccccccc}
\hline Models & $\begin{array}{c}\mathbf{T}_{\mathbf{a}} \\
\left({ }^{\circ} \mathbf{C}\right)\end{array}$ & $\begin{array}{c}\mathbf{T}_{\mathbf{r}} \\
\left({ }^{\circ} \mathbf{C}\right)\end{array}$ & $\begin{array}{c}\mathbf{R}_{\mathbf{h}} \\
\mathbf{( \% )}\end{array}$ & $\begin{array}{c}\mathbf{V}_{\mathbf{a}} \\
(\mathbf{m} / \mathbf{s})\end{array}$ & $\begin{array}{c}\mathbf{M}_{\mathbf{e}} \\
(\mathbf{m e t})\end{array}$ & $\begin{array}{c}\mathbf{C l} \\
(\mathbf{C l o})\end{array}$ & $\mathbf{P M V}$ & $\begin{array}{c}\text { PPD } \\
(\mathbf{\%})\end{array}$ & Thermal Sensation \\
\hline Model 0 & 24 & 24 & 72.35 & 0.05 & 1.1 & 0.57 & -0.11 & 6 & Neutral \\
\hline Model 1 & 24.5 & 24.5 & 72.35 & 0.05 & 1.1 & 0.57 & 0.06 & 5 & Neutral \\
\hline Model 2 & 25 & 25 & 72.35 & 0.05 & 1.1 & 0.57 & 0.23 & 6 & Neutral \\
\hline Model 3 & 25.5 & 25.5 & 72.35 & 0.05 & 1.1 & 0.57 & 0.39 & 8 & Neutral \\
\hline Model 4 & 26 & 26 & 72.35 & 0.05 & 1.1 & 0.57 & 0.56 & 12 & Neutral \\
\hline
\end{tabular}

Complies with ASHRAE Standard 55-2017: Model 1-3. Complies with EN-16798-1: Model 1-4.

To have an optimum air temperature based on thermal comfort and energy efficiency, cooling energy consumption for the suggested models is calculated. In addition, considering PMV overestimation, it can be deduced that Model 4 with $26^{\circ} \mathrm{C}$-with $0.5^{\circ} \mathrm{C}$ difference compared to Model 3-is acceptable for occupants in the real world.

The energy calculation allows investigating the potential of energy saving for cooling the indoor environment. Average measured indoor air temperature versus outdoor temperature is shown in Figure 11. The measured temperatures indicate that, although outdoor temperature increases, the indoor temperate stays in a constant range around $24{ }^{\circ} \mathrm{C}$. which means that the HVAC system consumes more energy in hotter hours in order to maintain indoor air temperature.

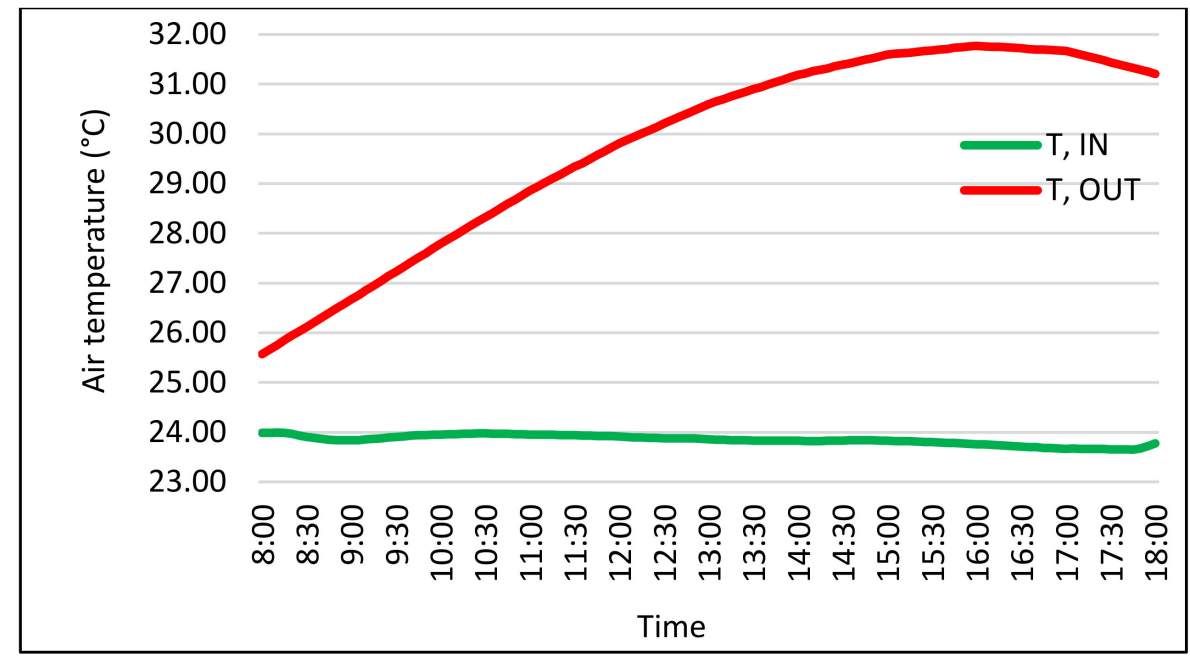

Figure 11. Indoor vs. outdoor temperature.

The building's facade is a double-glazed curtain wall (low-E glass double-glazed curtain) in the south and east to allow daylight penetration. The north and west sides of the building were constructed using reinforced concrete with minimum openings. The roof was covered by turf to minimize solar heat gain (U value of 0.43 ). Heat conduction through walls and windows was calculated by applying Equations (1) to (15). The equations were implemented in Python. Figure 12 shows that the schematic heat transfer through this building envelopes at 4 p.m. on 1 July. 


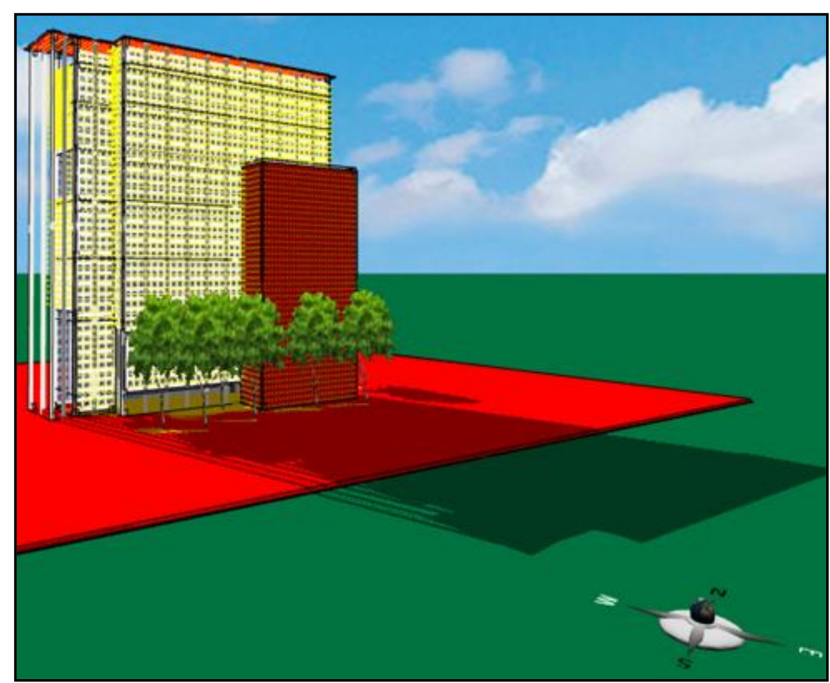

(a)

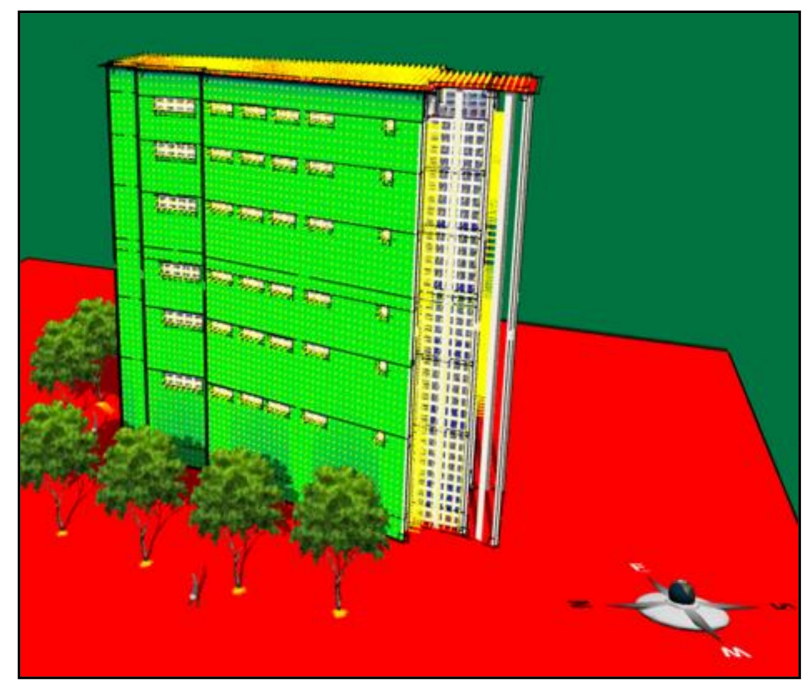

(b)

Figure 12. Schematic of heat transfer. (a) East view; (b) north view.

The solar heating gain coefficient (SHGC) of glazing in the west and east facades is around 0.37 , and in the north and south facades, it is 0.46 , with an emissivity of 0.16 and a $U$ value of 0.95 . According to Equation (4), the solar-air temperature was estimated by a sinusoidal model to calculate TETD. The calculated temperature for $24 \mathrm{~h}$ in Kuala Lumpur is shown in Figure 13. The comparison between calculated $\mathrm{T}_{\text {sa }}$ and measured $\mathrm{T}_{\text {out }}$ (Table 10) shows that the calculated sol-air temperatures are in good agreement with the outdoor temperature.

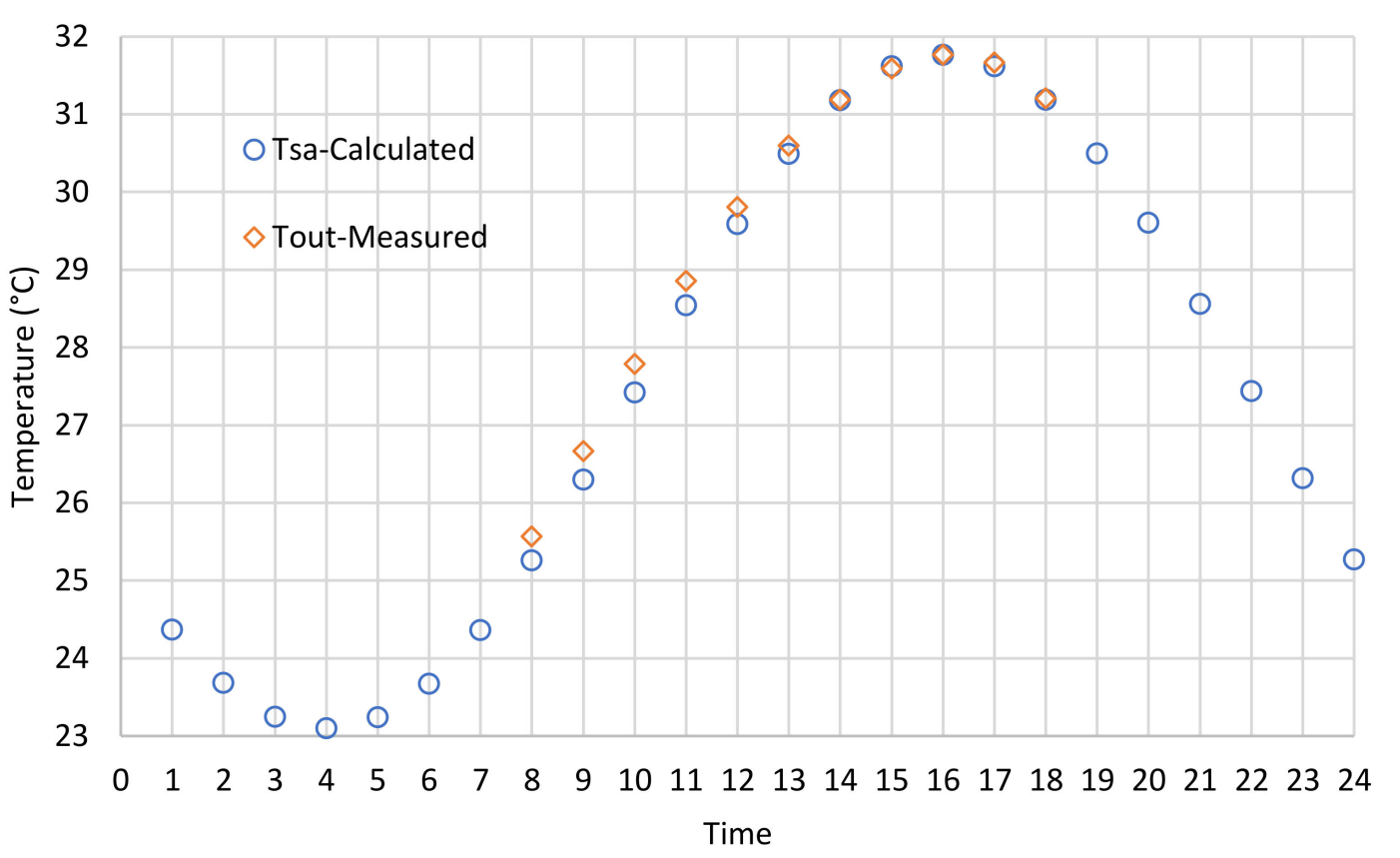

Figure 13. Sol-air and outdoor temperature. 
Table 10. Pearson's correlation between $\mathrm{T}_{\mathrm{sa}}$ and $\mathrm{T}_{\text {out }}$.

\begin{tabular}{|c|c|c|c|c|}
\hline \multirow{2}{*}{ Time } & \multirow{2}{*}{$\stackrel{\mathrm{T}_{\mathrm{sa}}}{\text { Calculated }}$} & \multirow{2}{*}{$\begin{array}{c}\mathrm{T}_{\text {out }} \\
\text { Measured }\end{array}$} & \multicolumn{2}{|c|}{ Correlation } \\
\hline & & & Pearson Correlation & Sig. (Two-Tailed) \\
\hline 8 & 25.25 & 25.57 & & \\
\hline 9 & 26.30 & 26.67 & & \\
\hline 10 & 27.42 & 27.79 & & \\
\hline 11 & 28.54 & 28.86 & & \\
\hline 12 & 29.59 & 29.81 & & \\
\hline 13 & 30.49 & 30.60 & $1.000 * *$ & 0.000 \\
\hline 14 & 31.18 & 31.19 & & \\
\hline 15 & 31.61 & 31.59 & & \\
\hline 16 & 31.77 & 31.77 & & \\
\hline 17 & 31.62 & 31.67 & & \\
\hline 18 & 31.18 & 31.21 & & \\
\hline
\end{tabular}

${ }^{* *}$ Correlation is significant at the 0.01 level (two-tailed).

The time lag and decrement factor of roof, walls, and windows were determined based on EN-ISO 13786 [53]. Thus, $\mathrm{T}_{\mathrm{Sa}, \varphi}$ was calculated according to the results. Then, the TETD of the roof, concrete walls and curtain walls was determined based on Equation (2) (Figure 14). This led to calculating the amount of heat transfer through conduction in different temperatures. As indicated in Figure 15, the cooling load can be reduced by increasing the set-point temperature during working hours in this office. As shown in Figure 16 the cooling power can be reduced by around $30 \%$ at 5 p.m. by increasing the set-point temperature to $26^{\circ} \mathrm{C}$.

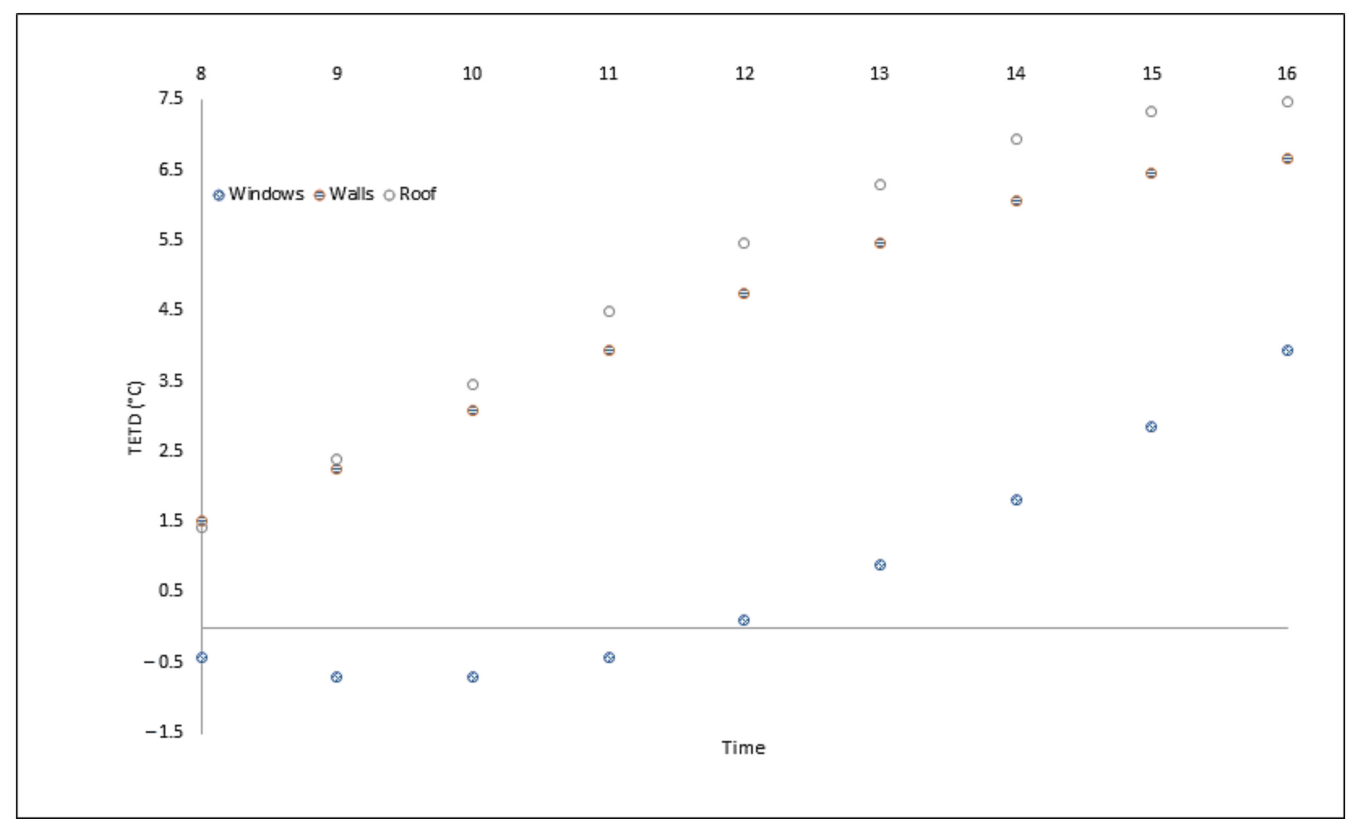

Figure 14. TETD of building envelopes at $24^{\circ} \mathrm{C}$. 


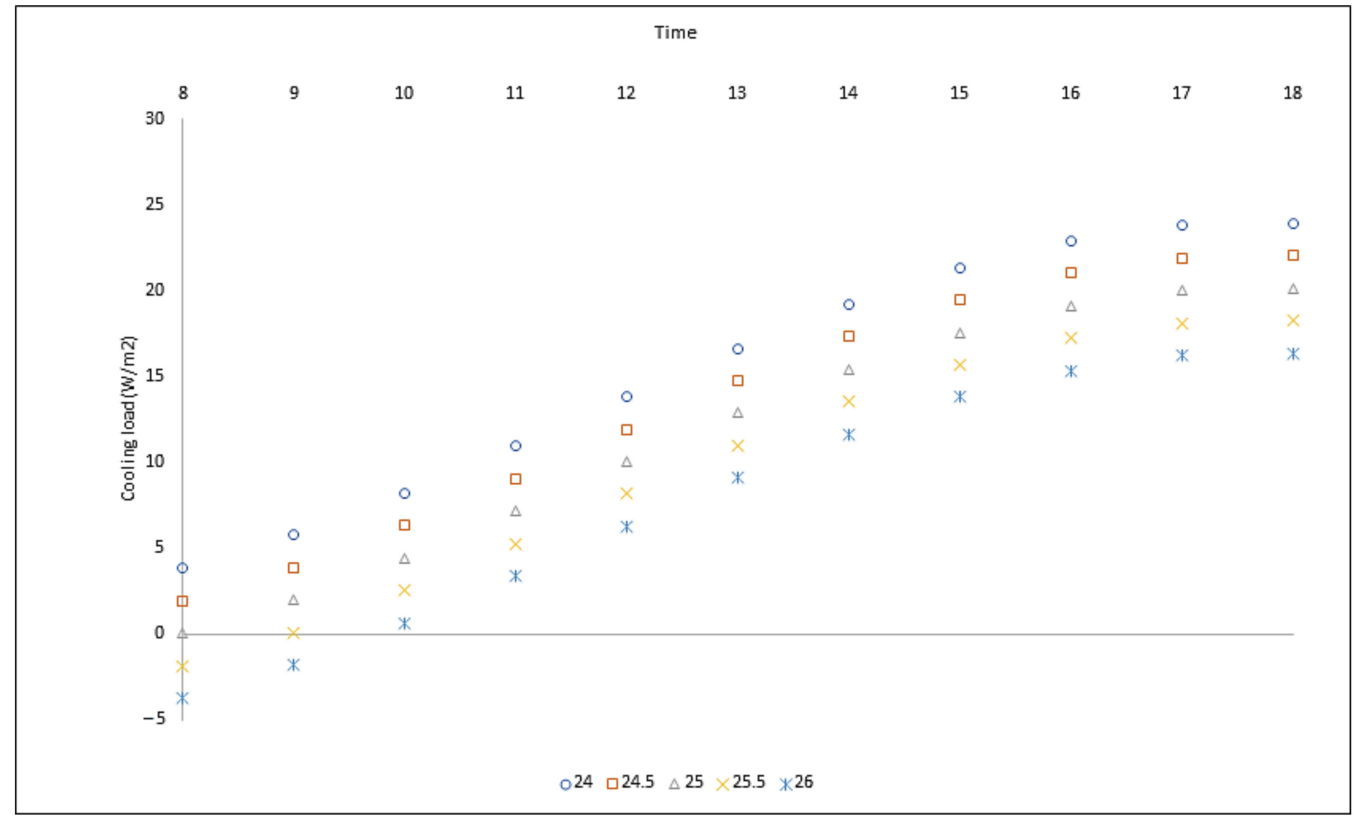

Figure 15. Hourly cooling load in different temperatures.

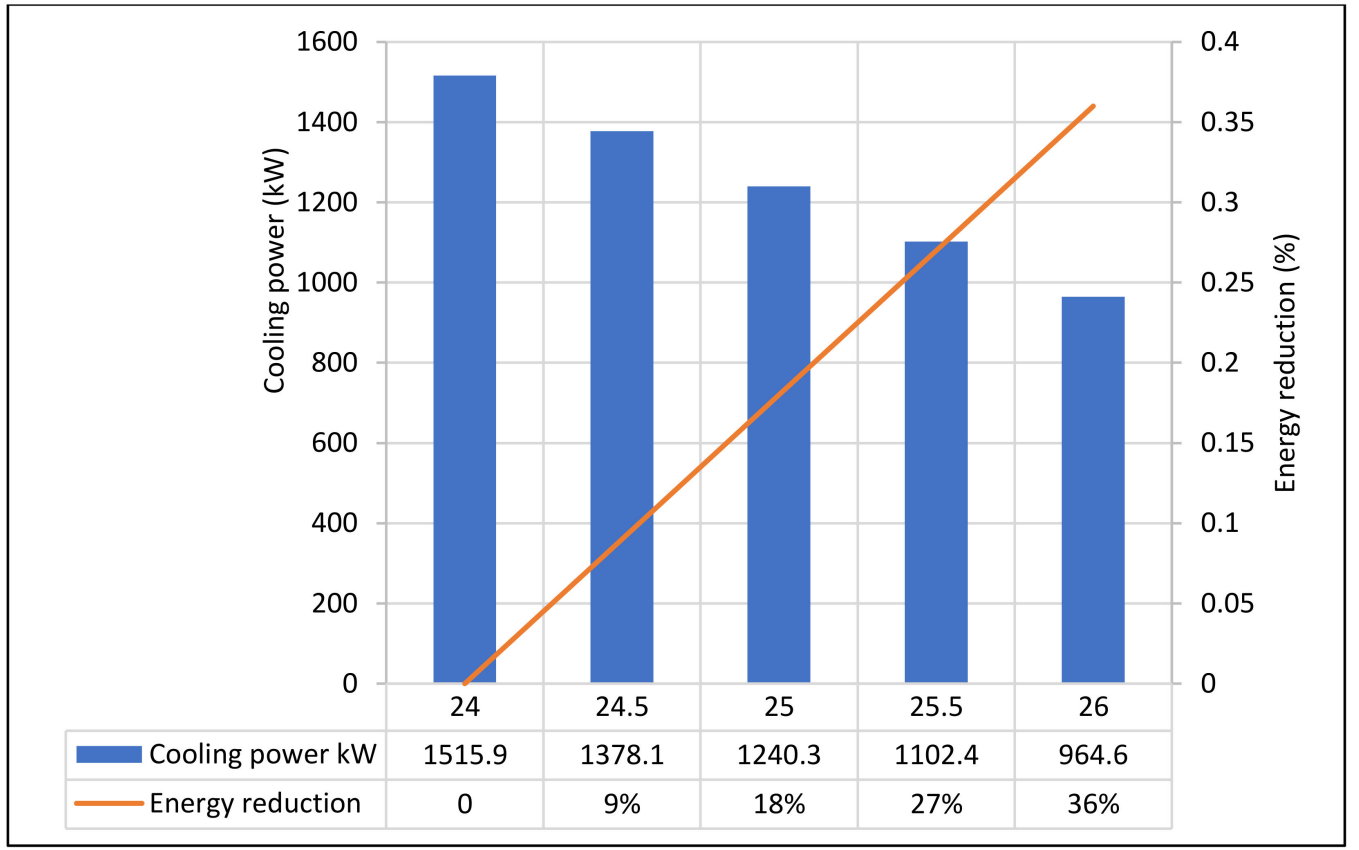

Figure 16. Total cooling load in different temperatures.

Total external cooling load is a function of both conduction and radiation heat transfer. The main radiation occurs through windows, which can be calculated by the following equation:

$$
\mathrm{Q}=\text { A. SC. ES. CF. SF }
$$

where A is the heat transfer area $\left(\mathrm{m}^{2}\right), \mathrm{SC}$ is shading coefficient, ES is external shading coefficient, $\mathrm{CF}$ is a correction factor for different orientations, and $\mathrm{SF}$ is the solar factor $\mathrm{W} / \mathrm{m}^{2}=194$ for Malaysia. Thus, the total external cooling load was determined for this building. The findings show that energy consumption tends to decrease with an increase of set-point temperature (Figure 16). In addition, the neutral temperature is at $24.3^{\circ} \mathrm{C}$, with a cooling load of $1427.8 \mathrm{~kW}$ (Figure 16). As shown in Figure 17 the intersection points between PMV and cooling power is at $24.9^{\circ} \mathrm{C}$. At this point, the PMV is 0.2, PPD is $6 \%$, and 
cooling power is $1262.3 \mathrm{~kW}$. It reveals that by $0.6{ }^{\circ} \mathrm{C}$ increments in set-point temperature, energy usage reduces around $11.6 \%$, and PPD increases by $1 \%$. Furthermore, the cooling power decreases $36 \%$ by setting the indoor temperature to $26^{\circ} \mathrm{C}$. This point is the minimum of the cooling power, with an acceptable PMV-PPD.

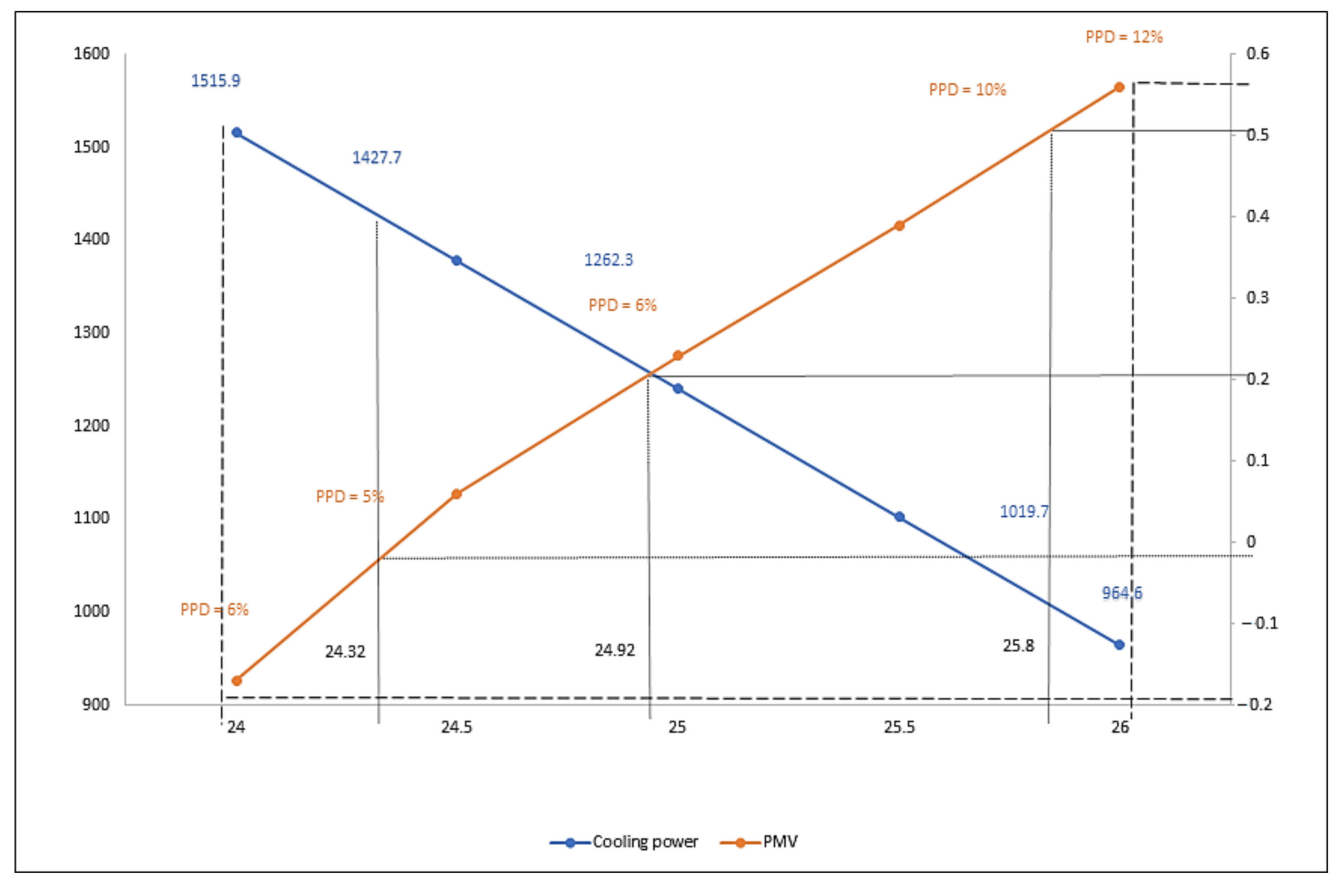

Figure 17. Optimum temperature based on PMV and cooling power.

Concerning cooling load demand, green construction aims to meet energy-saving policies at international, national, and regional levels. The findings indicate overworking of the HVAC system increases the cooling load in contrast to green construction goals. Although the building under this study was considered energy efficient, the findings implied overworking of the HVAC system resulted in thermal dissatisfaction. Thus, an increase of air temperature from 23.8 to $26^{\circ} \mathrm{C}$ is suggested to reduce cooling load by up to $36 \%$ annually and to improve thermal satisfaction. Similarly, a study by Aynsley [75] suggested the following equation to predict the neutral temperature based on outdoor dry bulb temperature in Southeast Asia.

$$
\mathrm{T}_{\mathrm{n}}\left( \pm 3.5^{\circ} \mathrm{C}\right)=17.6+0.31 \mathrm{~T}_{\mathrm{m}}
$$

Using Equation (18), the neutral temperature for Kuala Lumpur, with a mean temperature of $28^{\circ} \mathrm{C}$ is $26.2 \pm 3.5^{\circ} \mathrm{C}$. This is in alignment with the suggestion of this study. In addition, the proposed temperature by other studies in this region is summarized in Table 11.

Table 11. Comparison of neutral temperatures.

\begin{tabular}{cccc}
\hline Location & Type of Building & Temperature $\left({ }^{\circ} \mathbf{C}\right)$ & Reference \\
\hline Malaysia & GBI Office building & 26 & This study \\
Singapore & Office and Residential & 24.2 & De Dear and Brager [76] \\
Indonesia & Office & 26.7 & Karyono [77] \\
\hline
\end{tabular}

\section{Conclusions}

This study aimed to investigate: (a) thermal quality and (b) energy cooling demand to optimize thermal satisfaction and energy efficiency for a GBI Platinum-certified office building in Malaysia within a tropical climate. The filed investigation was taken into action to investigate thermal quality subjectively and objectively. The subjective investigation 
included a questionnaire survey and measurement of air temperature, relative humidity, and air velocity as objective investigations. To calculate cooling energy demand, the TETD method was applied to the study with the utilization of Python to calculate the equations. Fanger's PMV-PPD model was also applied to suggest a range of neutral air temperatures.

The findings indicated that $77.4 \%$ of occupants reported cool thermal sensation, with only $22.6 \%$ reporting overall thermal comfort. Statistical analyses revealed that there is no significant thermal difference according to gender, but office type made a significant difference for thermal sensation. Measuring thermal variables showed an average air temperature of $23.8^{\circ} \mathrm{C}$, average high relative humidity of $72 \%$, and low air velocity with a mean of $0.05 \mathrm{~m} / \mathrm{s}$. Under these circumstances, the mean TSV was observed to be -1.25 , indicating cool sensations out of the acceptable range. This finding highlighted the overworking of the HVAC system, resulting in extreme energy consumption.

To optimize the air temperature according to cooling load and thermal satisfaction, Fanger's PMV-PPD was employed to predict neutral air temperatures with consideration of the overestimation observed between PMV and TSV. Besides, the cooling load demand is calculated for various air temperatures, which indicated a $36 \%$ cooling load energy reduction by rising the cooling setpoint to $26^{\circ} \mathrm{C}$ indoor air temperature. Under this, the occupant's thermal satisfaction can be increased, while the cooling energy demand can be reduced.

Providing a thermally comfortable indoor environment for green buildings can be challenging in Malaysia due to the hot tropical climate. The cooling indoor environment needs a considerable amount of energy or special methods of design with natural ventilation to provide a thermally comfortable indoor environment. Thus, the conflict between energy-saving and occupant thermal satisfaction needs special attention to meet green building objectives, while maintaining a thermally comfortable indoor environment. Findings of this research demonstrated that delivering a thermally comfortable indoor environment to satisfy occupants requires more in-depth and sociological investigation, rather than just complying with ISO/OSHA standards. These findings can be utilized to improve universal and local standards and policies related to thermal comfort and energy consumption particularly related to tropical climate. Finally, this study provided new knowledge on occupant satisfaction from thermal quality and introduced new findings on building performance by proposing an optimum air temperature for a tropical climate.

Author Contributions: Conceptualization, M.E.; methodology, M.E., S.M.Z. and M.A.I.; software, M.E. and I.A.; formal analysis, S.M.Z., M.R.H., I.A. and S.M.; investigation, M.E., S.M.Z. and M.A.I.; resources, S.M.Z., M.R.H. and S.M.; data curation, M.E. and I.A.; writing-original draft preparation, M.E. and S.M.Z.; writing-review and editing, M.E., I.A. and S.M.; supervision, S.M.Z. and M.A.I.; funding acquisition, S.M.Z. and M.R.H. All authors have read and agreed to the published version of the manuscript.

Funding: This research was funded by MALAYSIA'S MINISTRY OF HIGHER EDUCATION FUNDAMENTAL RESEARCH GRANT SCHEME, grant number FRGS/1/2019/SSI11/UM/02/5.

Institutional Review Board Statement: Not applicable.

Informed Consent Statement: Not applicable.

Data Availability Statement: The data presented in this study are available on request from the corresponding authors. The data are not publicly available due to confidentiality.

Conflicts of Interest: The authors declare no conflict of interest. The funders had no role in the design of the study; in the collection, analyses, or interpretation of data; in the writing of the manuscript, or in the decision to publish the results. 


\section{References}

1. Che, W.W.; Tso, C.Y.; Sun, L.; Ip, D.Y.K.; Lee, H.; Chao, C.Y.H.; Lau, A.K.H. Energy consumption, indoor thermal comfort and air quality in a commercial office with retrofitted heat, ventilation and air conditioning (HVAC) system. Energy Build. 2019, 201, 202-215. [CrossRef]

2. Kwong, Q.J.; Adam, N.M.; Sahari, B.B. Thermal comfort assessment and potential for energy efficiency enhancement in modern tropical buildings: A review. Energy Build. 2014, 68, 547-557. [CrossRef]

3. Liang, H.-H.; Chen, C.-P.; Hwuang, R.-L.; Shih, W.-M.; Lo, S.-C.; Liao, H.-Y. Satisfaction of occupants toward indoor environment quality of certified green office buildings in Taiwan. Build. Environ. 2014, 72, 232-242. [CrossRef]

4. Catalina, T.; Iordache, V. IEQ assessment on schools in the design stage. Build. Environ. 2012, 49, 129-140. [CrossRef]

5. Corgnati, S.P.; Ansaldi, R.; Filippi, M. Thermal comfort in Italian classrooms under free running conditions during mid seasons: Assessment through objective and subjective approaches. Build. Environ. 2009, 44, 785-792. [CrossRef]

6. Aflaki, A.; Mahyuddin, N.; Mahmoud, Z.A.-C.; Baharum, M.R. A review on natural ventilation applications through building façade components and ventilation openings in tropical climates. Energy Build. 2015, 101, 153-162. [CrossRef]

7. Moosavi, L.; Mahyuddin, N.; Ab Ghafar, N.; Azzam Ismail, M. Thermal performance of atria: An overview of natural ventilation effective designs. Renew. Sustain. Energy Rev. 2014, 34, 654-670. [CrossRef]

8. Papadopoulos, A.M.; Oxizidis, S.; Papandritsas, G. Energy, economic and environmental performance of heating systems in Greek buildings. Energy Build. 2008, 40, 224-230. [CrossRef]

9. Hoyt, T.; Lee, K.H.; Zhang, H.; Arens, E.; Webster, T. Energy Savings from Extended Air Temperature Setpoints and Reductions in Room Air Mixing; Center for the Built Environment, UC Berkeley: Berkeley, CA, USA, 2005.

10. PTM. Pusat Tenaga Malaysia. Available online: https://www.greentechmalaysia.my/about/green-energy-office/ (accessed on 21 September 2020).

11. MS 1525. Energy Efficiency and Use of Renewable Energy for Non-Residential Buildings-Code of Practice; Malaysian Standard: Kuala Lumpur, Malaysia, 2019.

12. Hwang, R.-L.; Lin, T.-P.; Kuo, N.-J. Field experiments on thermal comfort in campus classrooms in Taiwan. Energy Build. 2006, 38, 53-62. [CrossRef]

13. ISO 7730. Ergonomics of the thermal environment-Analytical determination and interpretation of thermal comfort using calculation of the PMV and PPD indices and local thermal comfort criteria. Management 2005, 3, e615.

14. EN 16798-1:2019. Energy Performance of Buildings_Ventilation for Buildings_Part 1: Indoor Environmental Input Parameters for Design and Assessment of Energy Performance of Buildings Addressing Indoor Air Quality, Thermal Environment, Lighting and Acoustics-Module M1-6; European Standardization Organizations: Brussels, Belgium, 2019.

15. ASHRAE Standard 55. Standard 55, Thermal Environmental Conditions for Human Occupancy; ASHRAE Inc.: Atlanta, GA, USA, 2017.

16. Fanger, P.O. Thermal Comfort. Analysis and Applications in Environmental Engineering; Danish Technical Press: Copenhagen, Denmark, 1970.

17. Nicol, F. Adaptive thermal comfort standards in the hot-humid tropics. Energy Build. 2004, 36, 628-637. [CrossRef]

18. ISO. International Standard 7730, Moderate Thermal Environments: Determination of PMV and PPD Indices and Specification of the Conditions for Thermal Comfort; ISO: Geneva, Switzerland, 1994.

19. Damiati, S.A.; Zaki, S.A.; Rijal, H.B.; Wonorahardjo, S. Field study on adaptive thermal comfort in office buildings in Malaysia, Indonesia, Singapore, and Japan during hot and humid season. Build. Environ. 2016, 109, 208-223. [CrossRef]

20. Singh, M.K.; Mahapatra, S.; Atreya, S.K. Adaptive thermal comfort model for different climatic zones of North-East India. Appl. Energy 2011, 88, 2420-2428. [CrossRef]

21. Zhang, Y.; Wang, J.; Chen, H.; Zhang, J.; Meng, Q. Thermal comfort in naturally ventilated buildings in hot-humid area of China. Build. Environ. 2010, 45, 2562-2570. [CrossRef]

22. Rupp, R.F.; Vásquez, N.G.; Lamberts, R. A review of human thermal comfort in the built environment. Energy Build. 2015, 105, 178-205. [CrossRef]

23. Maykot, J.K.; Rupp, R.F.; Ghisi, E. Assessment of gender on requirements for thermal comfort in office buildings located in the Brazilian humid subtropical climate. Energy Build. 2018, 158, 1170-1183. [CrossRef]

24. Lovins, A. Air-Conditioning Comfort: Behavioral and Cultural Issues; E Source, Inc.: Boulder, CO, USA, 1992.

25. Jamaludin, N.; Mohammed, N.I.; Khamidi, M.F.; Wahab, S.N.A. Thermal Comfort of Residential Building in Malaysia at Different Micro-climates. Procedia-Soc. Behav. Sci. 2015, 170, 613-623. [CrossRef]

26. Asadi, I.; Hussein, I.; Palanisamy, K. Analysis on thermal comfort of air-conditioned buildings in Malaysia: Case study of Universiti Tenaga Nasional. In Applied Mechanics and Materials; Trans Tech Publications Ltd.: Bäch, Switzerland, 2014; pp. 1665-1669.

27. Yau, Y.H.; Chew, B.T.; Saifullah, A.Z.A. A Field Study on Thermal Comfort of Occupants and Acceptable Neutral Temperature at the National Museum in Malaysia. Indoor Built Environ. 2011, 22, 433-444. [CrossRef]

28. Ahmad, S.; Szokolay, S. The performance of a partially air conditioned apartment building in Kuala Lumpur. In Proceedings of the 24th International Conference on Passive and Low Energy Architecture, PLEA 2007, Singapore, 22-24 November 2007; pp. 225-231. 
29. Mahlia, T.M.I.; Taufiq, B.N.; Ismail; Masjuki, H.H. Correlation between thermal conductivity and the thickness of selected insulation materials for building wall. Energy Build. 2007, 39, 182-187. [CrossRef]

30. Esfandiari, M.; Mohamed Zaid, S.; Ismail, M.A.; Reza Hafezi, M.; Asadi, I.; Mohammadi, S.; Vaisi, S.; Aflaki, A. Occupants' Satisfaction toward Indoor Environment Quality of Platinum Green-Certified Office Buildings in Tropical Climate. Energies 2021, 14, 2264. [CrossRef]

31. Federspiel, C.C.; Bridges, B.; Langkilde, G. Statistical analysis of unsolicited thermal sensation complaints in commercial buildings/Discussion. ASHRAE Trans. 1998, 104, 912.

32. Bansal, K.; Chowdhury, S.; Gopal, M.R. Development of CLTD values for buildings located in Kolkata, India. Appl. Therm. Eng. 2008, 28, 1127-1137. [CrossRef]

33. Yumrutaş, R.; Kaşka, Ö.; Yıldırım, E. Estimation of total equivalent temperature difference values for multilayer walls and flat roofs by using periodic solution. Build. Environ. 2007, 42, 1878-1885. [CrossRef]

34. Dlimi, M.; Iken, O.; Agounoun, R.; Zoubir, A.; Kadiri, I.; Sbai, K. Energy performance and thickness optimization of hemp wool insulation and air cavity layers integrated in Moroccan building walls'. Sustain. Prod. Consum. 2019, 20, 273-288. [CrossRef]

35. Mazzeo, D.; Oliveti, G.; Arcuri, N. Influence of internal and external boundary conditions on the decrement factor and time lag heat flux of building walls in steady periodic regime. Appl. Energy 2016, 164, 509-531. [CrossRef]

36. Ozel, M. Thermal, economical and environmental analysis of insulated building walls in a cold climate. Energy Convers. Manag. 2013, 76, 674-684. [CrossRef]

37. GBI. GBI AssesSment Criteria for NON-RESIDENTIAL NEW CONSTRUCTION (NRNC); GBI: Kuala Lumpur, Malaysia, 2009.

38. Kothari, C.R. Research Methodology: Methods and Techniques; New Age International: New Delhi, India, 2008.

39. Zhang, C.; Pomianowski, M.; Heiselberg, P.K.; Yu, T. A review of integrated radiant heating/cooling with ventilation systemsThermal comfort and indoor air quality. Energy Build. 2020, 223, 110094. [CrossRef]

40. Marcel, L.; Katharina, S.; Wilfried, R.E. Indoor heat stress: An assessment of human bioclimate using the UTCI in different buildings in Berlin. ERDE J. Geogr. Soc. Berl. 2014, 144, 260-273. [CrossRef]

41. Kántor, N.; Unger, J. The most problematic variable in the course of human-biometeorological comfort assessment-The mean radiant temperature. Cent. Eur. J. Geosci. 2011, 3, 90-100. [CrossRef]

42. Matzarakis, A.; Amelung, B. Physiological equivalent temperature as indicator for impacts of climate change on thermal comfort of humans. In Seasonal Forecasts, Climatic Change and Human Health; Springer: Berlin/Heidelberg, Germany, 2008 ; pp. 161-172.

43. ISO 16000-1. Indoor Air-Part 1: General Aspects of Sampling Strategy; International Organization for Standardization: Geneva, Switzerland, 2007.

44. Ilesanmi, O.A. Post-occupancy evaluation and residents' satisfaction with public housing in Lagos, Nigeria. J. Build. Apprais. 2010, 6, 153-169. [CrossRef]

45. Seppänen, O.A.; Fisk, W. Some Quantitative Relations between Indoor Environmental Quality and Work Performance or Health. HVACR Res. 2006, 12, 957-973. [CrossRef]

46. Preiser, W.F.E.; Vischer, J.C. Assessing Building Performance; Routledge: London, UK, 2006.

47. Cochran, W.G. Sampling Techniques; Wiley: Hoboken, NJ, USA, 1977.

48. Asadi, I.; Shafigh, P.; Mahyuddin, N.B.; Akbari, H. Determination of optimum insulation and cement plaster thickness for bungalow buildings through a simulation-statistical approach using response surface methodology. J. Des. Built Environ. 2019, 19, 48-63. [CrossRef]

49. Mirrahimi, S.; Mohamed, M.F.; Haw, L.C.; Ibrahim, N.L.N.; Yusoff, W.F.M.; Aflaki, A. The effect of building envelope on the thermal comfort and energy saving for high-rise buildings in hot-humid climate. Renew. Sustain. Energy Rev. 2016, 53, 1508-1519. [CrossRef]

50. METEONORM v. 7. Global Meteorological Database for Applied Climatology; Meteotest: Bern, Switzerland, 2017.

51. Yumrutaş, R.; Ünsal, M.; Kanoğlu, M. Periodic solution of transient heat flow through multilayer walls and flat roofs by complex finite Fourier transform technique. Build. Environ. 2005, 40, 1117-1125. [CrossRef]

52. Oktay, H.; Yumrutaş, R.; Işik, M.Z. Comparison of Cltd and Tetd Cooling Load Calculation Methods for Different Building Envelopes. Mugla J. Sci. Technol. 2020, 6, 18-26. [CrossRef]

53. ISO 13786. Thermal Performance of Building Components-Dynamic Thermal Characteristics-Calculation Methods; European Committee for Standardization: Brussels, Belgium, 1999.

54. ISO 6946. Building Components and Building Elements-Thermal Resistance and Thermal Transmittance-Calculation Method; Committee for Standardization: London, UK, 2007.

55. Wolkoff, P.; Azuma, K.; Carrer, P. Health, work performance, and risk of infection in office-like environments: The role of indoor temperature, air humidity, and ventilation. Int. J. Hyg. Environ. Health 2021, 233, 113709. [CrossRef]

56. Yin, H.; Zhong, Y.; Wang, H.; Hu, J.; Xia, S.; Xiao, Y.; Nie, S.; Xie, M. Short-term exposure to high relative humidity increases blood urea and influences colonic urea-nitrogen metabolism by altering the gut microbiota. J. Adv. Res. 2021. [CrossRef]

57. Lechner, N. Heating, Cooling, Lighting: Sustainable Design Methods for Architects; John Wiley \& Sons: Hoboken, NJ, USA, 2014.

58. Khovalyg, D.; Kazanci, O.B.; Halvorsen, H.; Gundlach, I.; Bahnfleth, W.P.; Toftum, J.; Olesen, B.W. Critical review of standards for indoor thermal environment and air quality. Energy Build. 2020, 213, 109819. [CrossRef]

59. Kiki, G.; Kouchadé, C.; Houngan, A.; Zannou-Tchoko, S.J.; André, P. Evaluation of thermal comfort in an office building in the humid tropical climate of Benin. Build. Environ. 2020, 185, 107277. [CrossRef] 
60. Alotaibi, B.S.; Lo, S.; Southwood, E.; Coley, D. Evaluating the suitability of standard thermal comfort approaches for hospital patients in air-conditioned environments in hot climates. Build. Environ. 2020, 169, 106561. [CrossRef]

61. Wang, H.; Sun, L.; Guan, H.; Hu, S. Thermal environment investigation and analysis on thermal adaptation of workers in a rubber factory. Energy Build. 2018, 158, 1625-1631. [CrossRef]

62. $\mathrm{Wu}, \mathrm{T}$;; Cao, B.; Zhu, Y. A field study on thermal comfort and air-conditioning energy use in an office building in Guangzhou. Energy Build. 2018, 168, 428-437. [CrossRef]

63. Maiti, R. PMV model is insufficient to capture subjective thermal response from Indians. Int. J. Ind. Ergon. 2014, 44, 349-361. [CrossRef]

64. Yau, Y.; Chew, B. A review on predicted mean vote and adaptive thermal comfort models. Build. Serv. Eng. Res. Technol. 2014, 35, 23-35. [CrossRef]

65. Croome, D.; Gan, G.; Awbi, H. Thermal comfort and air quality in offices. Indoor Air 1993, 93, 37-42.

66. Howell, W.C.; Kennedy, P.A. Field validation of the Fanger thermal comfort model. Hum. Factors 1979, 21, 229-239. [CrossRef]

67. Mohammadi, S.; de Vries, B.; Rafiee, A.; Esfandiari, M.; Dias, E. An exploratory study on the impact of physical and geospatial characteristics of the urban built environment on the buildings annual electricity usage. J. Build. Eng. 2021, 40, 102359. [CrossRef]

68. Doherty, T.; Arens, E.A. Evaluation of the physiological bases of thermal comfort models. ASHRAE Trans. 1988, 94, $1371-1385$.

69. Koelblen, B.; Psikuta, A.; Bogdan, A.; Annaheim, S.; Rossi, R.M. Thermal sensation models: A systematic comparison. Indoor Air 2017, 27, 680-689. [CrossRef]

70. Peeters, L.; de Dear, R.; Hensen, J.; D'haeseleer, W. Thermal comfort in residential buildings: Comfort values and scales for building energy simulation. Appl. Energy 2009, 86, 772-780. [CrossRef]

71. Holmes, M.J.; Hacker, J.N. Climate change, thermal comfort and energy: Meeting the design challenges of the 21st century. Energy Build. 2007, 39, 802-814. [CrossRef]

72. ASHRAE. ASHRAE Handbook-Fundamentals; American Society of Heating, Refrigerating and Air-Conditioning EngineersASHRAE: Atlanta, GA, USA, 2009.

73. Walikewitz, N.; Jänicke, B.; Langner, M.; Meier, F.; Endlicher, W. The difference between the mean radiant temperature and the air temperature within indoor environments: A case study during summer conditions. Build. Environ. 2015, 84, 151-161. [CrossRef]

74. Li, D.; Menassa, C.C.; Kamat, V.R.; Byon, E. HEAT-Human Embodied Autonomous Thermostat. Build. Environ. 2020, 178, 106879. [CrossRef]

75. Aynsley, R. Low energy architecture for humid tropical climates. In Proceedings of the World Renewable Energy Congress, Kuala Lumpur, Malaysia, 8-11 June 1999; pp. 333-339.

76. De Dear, R.J.; Brager, G.S. Thermal comfort in naturally ventilated buildings: Revisions to ASHRAE Standard 55. Energy Build. 2002, 34, 549-561. [CrossRef]

77. Karyono, T.H. Report on thermal comfort and building energy studies in Jakarta-Indonesia. Build. Environ. 2000, 35, 77-90. [CrossRef] 